\title{
Tipping elements and amplified polar warming during the Last Interglacial
}

\author{
Zoë A. Thomas ${ }^{\mathrm{a}, \mathrm{b}, \mathrm{c}, *}$, Richard T. Jones ${ }^{\mathrm{d}, 1}$, Chris S.M. Turney ${ }^{\mathrm{a}, \mathrm{b}, \mathrm{c}}$, Nicholas Golledge $\mathrm{e}^{\mathrm{e}, \mathrm{f}}$, \\ Christopher Fogwill $^{g}$, Corey J.A. Bradshaw ${ }^{b, h}$, Laurie Menviel ${ }^{a, i}$, Nicholas P. McKay ${ }^{\mathrm{j}}$, Michael Bird ${ }^{\mathrm{b}, \mathrm{k}}$, \\ Jonathan Palmer ${ }^{\mathrm{a}, \mathrm{b}, \mathrm{c}}$, Peter Kershaw ${ }^{1}$, Janet Wilmshurst ${ }^{\mathrm{m}, \mathrm{n}}$, Raimund Muscheler ${ }^{\mathrm{o}}$
}

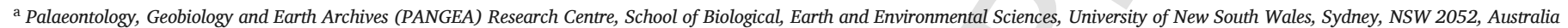

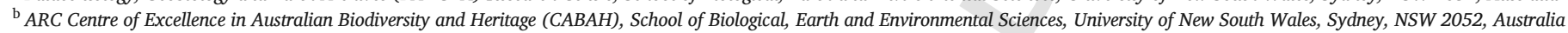

c Chronos 14 Carbon-Cycle Facility, University of New South Wales, Sydney NSW 2052, Australia

${ }^{\mathrm{d}}$ School of Geography, College of Life and Environmental Sciences, University of Exeter, Exeter, UK

e Antarctic Research Centre, Victoria University of Wellington, Wellington 6140, New Zealand

f GNS Science, Avalon, Lower Hutt 5011, New Zealand

${ }^{\mathrm{g}}$ School of Geography, Geology and the Environment, Keele University, Newcastle-under-Lyme, UK

${ }^{\mathrm{h}}$ Global Ecology, College of Science and Engineering, Flinders University, GPO Box 2100, South Australia 5001, Australia

${ }^{i}$ Climate Change Research Centre, University of New South Wales, Sydney, NSW, Australia

j School of Earth and Sustainability, Northern Arizona University, Arizona, USA

${ }^{\mathrm{k}}$ School of Earth and Environmental Sciences and Center for Tropical Environmental and Sustainability Science, James Cook University, Cairns, Queensland 4870, Australia

${ }^{1}$ School of Earth, Atmosphere and Environment, Monash University, Melbourne, Victoria, 3800, Australia

${ }^{\mathrm{m}}$ Long Term Ecology Laboratory, Landcare Research, Lincoln, New Zealand

${ }^{\mathrm{n}}$ School of Environment, University of Auckland, Private Bag 92019, Auckland 1142, New Zealand

${ }^{\circ}$ Quaternary Sciences, Department of Geology, Lund University, Sölvegatan 12, 22362 Lund, Sweden

\section{A R T I C L E I N F O}

\section{Article history:}

Received 24 October 2019

Received in revised form 7 Febraury 2020

Accepted 13 Febraury 2020

Available online $\mathrm{xxx}$

\begin{abstract}
A B S T R A C T
Irreversible shifts of large-scale components of the Earth system (so-called 'tipping elements') on policy-relevant timescales are a major source of uncertainty for projecting the impacts of future climate change. The high latitudes are particularly vulnerable to positive feedbacks that amplify change through atmosphere-ocean-ice interactions. Unfortunately, the short instrumental record does not capture the full range of past or projected climate scenarios (a situation particularly acute in the high latitudes). Natural archives from past periods warmer than present day, however, can be used to explore drivers and responses to forcing, and provide data against which to test models, thereby offering insights into the future. The Last Interglacial (129-116,000 years before present) - the warmest interglacial of the last 800,000 years - was the most recent period during which global temperatures were comparable with low-end 21st Century projections (up to $2{ }^{\circ} \mathrm{C}$ warmer, with temperature increase amplified over polar latitudes), providing a potentially useful analogue for future change. Substantial environmental changes happened during this time. Here we synthesise the nature and timing of potential high-latitude tipping elements during the Last Interglacial, including sea ice, extent of the boreal forest, permafrost, ocean circulation, and ice sheets/sea level, and review the thresholds and feedbacks that likely operated through this period. Notably, substantial ice mass loss from Greenland, the West Antarctic, and possibly sectors of the East Antarctic drove a 6-9 m rise in global sea level. This was accompanied by reduced summer sea-ice extent, poleward-extended boreal forest, and reduced areas of permafrost. Despite current chronological uncertainties, we find that tipping elements in the high latitudes all experienced rapid and abrupt change (within 1-2 millennia of each other) across both hemispheres, while recovery to prior conditions took place over multi-millennia. Our synthesis demonstrates important feedback loops between tipping elements, amplifying polar and global change during the Last Interglacial. The high sensitivity and tight interconnections between polar tipping elements suggests that they may exhibit similar thresholds of vulnerability in the future, particularly if the aspirations of the Paris Agreement are not met.
\end{abstract}

\footnotetext{
* Corresponding author. Palaeontology, Geobiology and Earth Archives (PANGEA) Research Centre, School of Biological, Earth and Environmental Sciences, University of New South Wales, Sydney, NSW 2052, Australia.

E-mail address: z.thomas@unsw.edu.au (Z.A. Thomas)

1 Deceased.
} 


\section{Introduction}

Abrupt and non-linear changes in the Earth System have important implications for predicting future climate change and constitute a large source of uncertainty for projections. While these types of changes have been a feature of the Earth System behaviour for millions of years (Alley et al., 2003; Thomas, 2016), predicting future impacts remains challenging. With Arctic sea-ice extent consistently breaking previous record lows (Kwok, 2018), the shift toward an ice-free summer state becomes increasingly possible, with ecological, environmental, climatic and even geopolitical implications for the wider Arctic region (Melia et al., 2016; Post et al., 2013; Screen and Williamson, 2017). At the other end of the globe, the projected contribution of Antarctic ice-sheet melt to 21st Century global mean sea level under an unmitigated emissions scenario ranges from a few decimetres (Edwards et al., 2019; Golledge et al., 2019, 2015; Levermann and Feldmann, 2019; Ritz et al., 2015) to more than a metre (DeConto and Pollard, 2016). Due to positive feedbacks within the Earth system, these changes at either pole are not independent; ocean-atmosphere interactions mean that the tipping of one sub-system into a different state could trigger the collapse of an inter-connected sub-system (Lenton and Ciscar, 2013; Lenton and Williams, 2013; Levermann et al., 2012; Steffen et al., 2007). This has been termed a 'tipping cascade' (Lenton and Williams, 2013). In the high latitudes in particular, feedbacks between sea ice, ocean circulation, permafrost, boreal forests, ice sheets and sea level mean that these regions are likely to warm more rapidly than the global mean, a phenomenon known as 'polar amplification' (Collins et al., 2013; Naish and Zwartz, 2012; Screen and Simmonds, 2013).

In 2016, 197 countries signed the Paris Agreement to limit 21st Century anthropogenic warming to $1.5-2{ }^{\circ} \mathrm{C}$ above pre-industrial baseline temperatures. Even at this 'lower-end' projection, the timing and potential impacts of abrupt and extreme climate-change events remain highly uncertain (Drijfhout et al., 2015). A major challenge is that historical records of climatic changes are too short (most since 1850) to fully elucidate complex climate processes, nor do they capture the full range of the projected climate scenarios (Bracegirdle et al., 2019). Natural archives from warmer periods in the past can be used to identify responses to forcing and modes of climate variability, providing a reference against which to test long-term projected simulations (Masson-Delmotte et al., 2013). The most recent period during which global/regional temperatures were comparable to the low-end (Paris Agreement) 21st Century projections was the Last Interglacial (129-116,000 years before present, or 129-116 ka), when peak global mean sea levels may have been 6-9 $\mathrm{m}$ higher than today (Dutton et al., 2015; Kopp et al., 2009; Overpeck et al., 2006) despite comparable atmospheric concentrations of greenhouse gases $\left(\mathrm{CO}_{2}\right.$ concentration at $\sim 278$ parts per million by volume and $\mathrm{CH}_{4}$ at $\sim 684$ parts per million by volume; Loulergue et al., 2008; Lüthi et al., 2008). While reconstructions of global temperatures during the Last Interglacial range from up to $2{ }^{\circ} \mathrm{C}$ higher than preindustrial conditions (Turney and Jones, 2010), to no significant difference (Capron et al., 2014; Hoffman et al., 2017), both proxy data and model simulations reconstruct the greatest warming occurring at polar latitudes. Indeed, Arctic maximum summer-temperature proxy-derived anomalies were recorded to be up to $8{ }^{\circ} \mathrm{C}$ warmer during the Last Interglacial than today, associated with large changes across the cryosphere (Cape Last Interglacial Project Members, 2006; NEEM community members, 2013). Note that we use the term 'Last Interglacial' to denote the period broadly correlating with the Eemian and Marine Isotope Stage (MIS) 5e/5.5 (129-116 ka; Dutton et al., 2015).

Although the Last Interglacial is not a perfect global analogue to today due to differences in the latitudinal distribution of insolation forcing and corresponding warming, climate and environmental records from this period can offer insights into the mechanisms and feedbacks that operate in a $1-2{ }^{\circ} \mathrm{C}$ warmer world. Indeed, the Paris Agreement to restrict global warming to $2{ }^{\circ} \mathrm{C}$ relative to the pre-industrial period is considered close to the threshold at which the West Antarctic ice sheet could become fully destabilised (Schellnhuber et al., 2016). Such an event could potentially drive future abrupt ice-sheet collapse and a rise in global sea level on the order of metres (Dutton et al., 2015), with substantial and irreversible consequences for the global climate and the environment in general (Bronselaer et al., 2018; Golledge et al., 2019; Steffen et al., 2018). Simulations of the Last Interglacial climate largely underestimate the magnitude of the changes suggested by proxy records (IPCC AR5, 2013), suggesting that there may be important positive feedbacks that are being overlooked (Braconnot et al., 2012; Capron et al., 2017; Nikolova et al., 2013), particularly in the polar regions (Goosse et al., 2018). For instance, 'polar amplification' is a phenomenon where changes in the net radiation balance (such as might be caused by an increase in greenhouse-gas concentration) tend to produce a larger change in climatic conditions near the poles than the global average (Serreze and Barry, 2011), a situation thought to be comparable to the 'rapid', high-latitude temperature response during the Last Interglacial (Clark and Huybers, 2009). However, questions remain regarding how quickly these changes occurred, the wider-scale impacts on the Earth system, and how these might inform our understanding of future climate patterns.

Here we synthesise the nature and timing of five high-latitude Last Interglacial 'tipping elements' - sea ice, boreal forest, permafrost, ocean circulation and ice sheets/sea level - using available proxy records. These Earth-system tipping elements can be considered as sub-continental scale components of the Earth system, that can be switched into 'a qualitatively different state by small perturbations' via system-level manifestations of non-linearity (Lenton et al., 2008). This includes systems where the transition is not necessarily faster than the forcing, as well as systems that might undergo a qualitative change as a result of small variations in the control parameter, but that do not necessarily cross a critical threshold (a deliberately broad definition). The specification of a political (100 yrs) and ethical (1000 yrs) time frame of change has the power to influence present-day decisions, and gives the definition a 'policy relevant dimension'. Many elements within the Earth's system are increasingly recognised to display this non-linear behaviour, and the term 'tipping point' has been used to variously describe phenomena such as positive feedbacks, hysteresis, irreversible transitions, multiple equilibria, bifurcations, and abrupt change (Dakos et al., 2014, 2008; Scheffer et al., 2009, 2001; Thomas, 2016; Thomas et al., 2015). In many of these cases, the transition from one state to another may not be directly reversible, a behaviour known as hysteresis, where the magnitude of forcing required to move in one direction is different to the force needed to move in the opposite direction (Fig. 1).

Recent literature discussing the trajectory of the Earth System to a 'hothouse' condition suggests certain temperature thresholds above which some elements will 'tip' into an alternative state. These include the Greenland ice sheet, West Antarctic ice sheet, and Arctic summer sea ice as vulnerable at $1-3{ }^{\circ} \mathrm{C}$ warming, boreal forest and thermohaline circulation at $3-5{ }^{\circ} \mathrm{C}$, and Arctic winter sea ice, permafrost, and the East Antarctic ice sheet at $>5{ }^{\circ} \mathrm{C}$ (although some sub-basins are vulnerable below this temperature) (Steffen et al., 2018). We discuss what natural archives from the Last Interglacial can tell us about this elicitation. The tipping elements discussed here do not form an exhaustive list, but highlight some of the most sensitive components of the Earth system for which behaviour during the Last Interglacial is a useful analogue, and for which we have sufficient information. While all climate proxies have limitations in terms of their preservation, climate sensitivity, seasonality, and chronological uncertainty, many are able to provide robust information about changes relative to today. We 


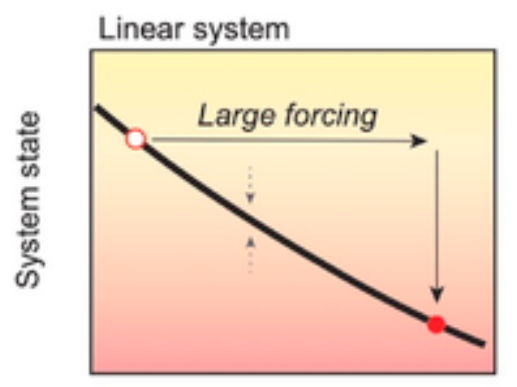

Non-linear system

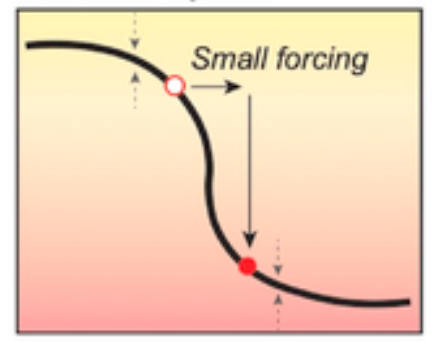

Non-linear system, with hysteresis

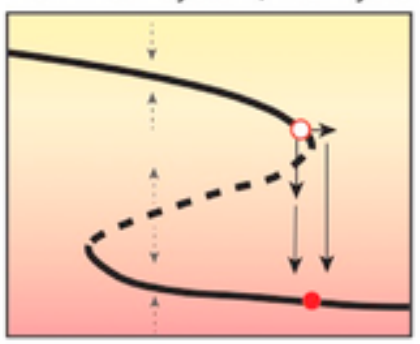

Conditions

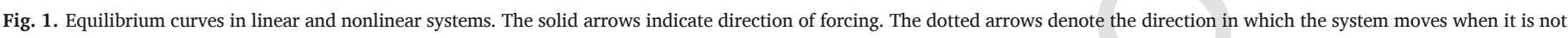
on the curve (and therefore not in equilibrium). Modified from Scheffer et al. (2009).

use simple criteria to identify the time a tipping element underwent a non-linear change beyond present-day limits. The proxy evidence we consider includes time series with change points representing local to regional scales, as well as networks of individual sites showing local presence/absence transitions. We also review the thresholds and feedbacks that likely operated during this time.

\section{High-latitude Earth-system tipping elements during the Last Interglacial}

\subsection{Sea ice}

Sea ice plays a fundamental role in the planetary surface energy balance, ecosystems, and sea-air interactions, as well as ocean and atmospheric circulation across a range of timescales (Goosse and Zunz, 2014; Hobbs et al., 2016; Jones et al., 2016; Screen, 2013; Turner et al., 2005; Wilson et al., 2016). The recent, substantial reduction in summer Arctic sea-ice extent $(-13.5 \pm 2.93 \%$ per decade change relative to the 1979-2015 average) (Peng and Meier, 2018), as well as thinning and the loss of multi-year ice (Kwok, 2018, 2007), is already having ecological, environmental and geopolitical impacts (IPCC AR5, 2013). Sea-ice extent is considered a potential tipping element due to the existence of positive feedbacks within the system (largely between sea-ice extent and albedo; Screen and Simmonds, 2010). Although sea-ice records during the Last Interglacial are sparse and subject to large uncertainty in chronology, evidence from polar ice and marine sediment cores suggests markedly reduced extent (Cape Last Interglacial Project Members, 2006; Nørgaard-Pedersen et al., 2007; Otto-Bliesner et al., 2006). In the Northern Hemisphere, while the central Arctic Ocean did remain covered by permanent sea ice throughout the Last Interglacial (Spielhagen et al., 2004), planktic foraminifera assemblages in marine sediment records from the Nordic Sea indicate that there was higher marine productivity during past interglacials, implying reduced sea-ice cover relative to present day (Løwemark et al., 2016; Nørgaard-Pedersen et al., 2007; Polyak et al., 2010; Svendsen et al., 2004). Direct evidence for increased productivity comes from marine cores in what is today a heavily ice-covered region of the Arctic Ocean north of Greenland, where a reduction of Last Interglacial sea ice is inferred from the presence of planktic foraminifera that are more typical of subpolar and seasonally open water (Løwemark et al., 2016; Nørgaard-Pedersen et al., 2007; Svendsen et al., 2004). Data from the western Arctic Ocean at 79 ${ }^{\circ} \mathrm{N}$ indicate an early retreat, with the peak in subpolar foraminifera occurring before $130 \mathrm{ka}$ (Adler et al., 2009). The presence of intertidal snails from Alaska has suggested a position of winter sea ice $\sim 800 \mathrm{~km}$ north of its present position, with the Bering Sea perennially ice free by the peak of the Last Interglacial (Brigham-Grette et al., 2001; Brigham-Grette and Hopkins, 1995). The regional expanse of ice-free conditions suggested by subpolar foraminifera species indicate ice-free summer conditions are more likely than locally occur- ring polynyas, although the precise timing is unclear given the relatively large uncertainties in the chronologies of marine sites (Cape Last Interglacial Project Members, 2006; Løwemark et al., 2016; Nørgaard-Pedersen et al., 2007).

In the Southern Hemisphere, sea-ice extent tends to be regionally asymmetric, with each sector influenced by different circulation patterns and modes (Holland et al., 2017; Hosking et al., 2013; Turner et al., 2015), although mean trends are analogous. Sea-salt records from two ice core drilling sites (Epping Dronning Maud Land; EDML and Epica Dome C; EDC), in the Atlantic and Indian sector of the East Antarctic ice sheet respectively, suggest a $50 \%$ reduction of winter sea-ice coverage when compared to the Holocene (Fischer et al., 2007), most of which took place by $128 \mathrm{ka}$ (Bianchi and Gersonde, 2002). In addition, four ice cores from the East Antarctic ice sheet all display $\delta^{18} \mathrm{O}$ maxima at $\sim 128$ ka (Holloway et al., 2016), associated with peak Antarctic warmth. While this isotope maximum is linked to the potential early loss of the West Antarctic ice sheet (Otto-Bliesner et al., 2013), an alternate idea invokes the reduction of Southern Hemisphere sea-ice extent (Holloway et al., 2016). Overall, while the precise rate and timing of sea-ice retreat is uncertain, the most substantial changes appear to have occurred by 130 and $128 \mathrm{ka}$ in the north and south, respectively.

\subsection{Polar ice sheets and sea level}

Sea-level rise is one of the most immediately concerning of the potential tipping elements, due to the major socio-economic impacts associated with inundation of coastlines (Neumann et al., 2015; Pycroft et al., 2016; Schaeffer et al., 2012). While global mean sea level has risen by $\sim 0.19 \mathrm{~m}$ over the 20th Century (Church et al., 2013), this rise has mostly been dominated by thermal expansion of the oceans and montane glacier mass loss (Dutton et al., 2015). However, melt from the Greenland and Antarctic ice sheets has been occurring at a progressively increasing rate since the turn of the century (Bevis et al., 2019; Rignot et al., 2011), dominating the global mean sea-level acceleration since the 1990s (Dangendorf et al., 2019). Recent estimates of peak global mean sea-level during the Last Interglacial have converged on a range of 6-9 $\mathrm{m}$ higher than the pre-industrial (Dutton et al., 2015; Grant et al., 2014; Kopp et al., 2009), although other work has suggested this range might still be too conservative (Rohling et al., 2017). Uncertainties in past sea-level reconstructions include calculating precise rates of uplift (Kopp et al., 2009), as well as dynamical changes in topography (Austermann et al., 2017). Given these estimates, the polar ice sheets must have been substantially smaller than today, but there is much debate regarding the exact contribution of different sources to this increased sea level. Mountain glaciers are thought to have contributed no more than $1 \mathrm{~m}$ (Clark and Huybers, 2009), or perhaps even less (0.6 $\pm 0.1 \mathrm{~m}$; (Radić 
and Hock, 2011), while thermal expansion provided a negligible $(0.4 \pm 0.3 \mathrm{~m})$ contribution (McKay et al., 2011).

The Greenland ice sheet was evidently smaller during the Last Interglacial compared to today (Colville et al., 2011), but there is a large range in its estimated contribution to global sea level (Helsen et al., 2013; Stone et al., 2013; Yau et al., 2016). The absence of a continuous record of undisturbed ice through the Last Interglacial in several locations is equivocal, e.g., Dye-3 and Camp Century (Otto-Bliesner et al., 2006; Stone et al., 2016), implying a drawdown (supported by isotope-derived elevation estimates) (Raynaud et al., 1997). Cosmogenic exposure dating of subglacial materials beneath the Summit region suggests Greenland Ice Sheet may have lost considerable (up to 90\%) mass (Schaefer et al., 2009); however, the presence of Last Interglacial-age ice from the Summit region, e.g., North Greenland Ice Core Project (NGRIP), Greenland Ice Core Project (GRIP) and Greenland Ice Sheet Project 2 (GISP2) (NGRIP members et al., 2004; Suwa et al., 2006) indicates that retreat was not complete. Additionally, the presence of ice at the North Greenland Eemian Ice Drilling site during the Last Interglacial provides direct evidence for the timing of changes in the Greenland ice sheet, but can only be reconciled with simulations contributing up to $2 \mathrm{~m}$ of global sea level rise (NEEM community members, 2013). The onset of melt is dated to $128 \mathrm{ka}$, marked by the initiation of surface lowering and the presence of surface melt layers, which are found throughout much of the Last Interglacial (NEEM community members, 2013). Elevation decrease occurred until $122 \mathrm{ka}$, where it remained at $\sim 300 \mathrm{~m}$ below present until the recovery of the ice sheet started at around $118 \mathrm{ka}$, well after the peak of Northern Hemisphere high-latitude insolation (Fig. 2). These timings are supported by analysis from Greenland Ice Sheet Project 2 (GISP2), which identifies an initiation of rapid deglacial warming at $126.7 \mathrm{ka}$ (Yau et al., 2016).

The West Antarctic ice sheet is likely to have retreated during the Last Interglacial, an idea first proposed by John Mercer half a century ago (Mercer, 1969, 1978), but precise values and sea level-equivalent volumes are contested. Even using the current most conservative estimates of global sea level $(6.6 \mathrm{~m})$, if only $\sim 2 \mathrm{~m}$ of this can be attributed to Greenland, and the West Antarctic ice sheet holds only $3.3 \mathrm{~m}$ sea-level equivalent (Bamber et al., 2009), this implies: (i) a total loss of the West Antarctic ice sheet, and (ii) possibly some loss from the East Antarctic ice sheet. However, direct physical evidence of mass loss from the West Antarctic ice sheet has been elusive (Fogwill et al., 2012; Hein et al., 2016; Steig and Huybers, 2015). Signatures of melting of the West Antarctic ice sheet can be derived from negative excursions of benthic $\delta^{13} \mathrm{C}$ records from the high-latitude South Atlantic and Pacific, and have been documented in several marine sediment cores from these area between 126-123 ka (Hodell et al., 2003; Pahnke and Zahn, 2005). However, the first in situ observations are reported from a blue-ice record of ice-sheet and environmental change from the periphery of the marine-based West Antarctic ice sheet. Combined tephra and trace gas analyses suggest a $\sim 50 \mathrm{k}$ hiatus in the Patriot Hills ice sequence after Termination II (130.7 $\pm 1.8 \mathrm{ka})$, implying substantial ice drawdown and contribution to sea level rise (Turney et al., 2020). This suggests an early loss of substantial ice mass from the West Antarctic, prior to the global mean sea level highstand (Fig. 2). While the East Antarctic ice sheet was once thought to be relatively stable (compared to its western counterpart), it also has large sectors that are marine-based ( $19 \mathrm{~m}$ sea-level equivalent; Fretwell et al., 2013), making it potentially vulnerable to retreat (Fogwill et al., 2014). Sedimentological and geochemical evidence from a marine sediment core shows provenance changes consistent with ice loss from the Wilkes Subglacial Basin at some point during the Last Interglacial. This topographic basin has a base $>1000 \mathrm{~m}$ below present sea level and holds an estimated 3-4 m sea-level equivalent (Fretwell et al., 2013; Mengel and Levermann, 2014). However, the exact timing of this ice melt and its contribution to sea level is uncertain (Wilson et al., 2018).

\subsection{Ocean circulation}

Global ocean circulation is fundamental to the storage and transfer of heat and salt throughout the ocean basins, and plays an important role in setting the climate as well as the cycling of nutrients and carbon. A slowdown of the Atlantic meridional overturning circulation (responsible for the transport of heat from the tropics to the mid to high latitudes), linked to a persistent subpolar North Atlantic cooling anomaly and warming in the Gulf Stream region, has been observed over the 20th Century (Caesar et al., 2018; Rahmstorf et al., 2015; Thornalley et al., 2018). In conjunction, there has been a widespread warming and freshening of Antarctic bottom water in recent decades (Menezes et al., 2017), with a resulting reduction in its northward extent. Strong Atlantic meridional overturning circulation is recorded from the start of the Last Interglacial ( $\sim 129 \mathrm{ka})$; however, there is substantial proxy evidence for a slowdown at $\sim 127-126 \mathrm{ka} \mathrm{BP}$, with several studies indicating concurrent iceberg discharges (Irvali et al., 2012; Nicholl et al., 2012). Rapid centennial-scale reductions of North Atlantic Deep Water formation have been recorded, indicating periods of increased ice rafting and southward expansion of polar waters during the Last Interglacial (Galaasen et al., 2014). Evidence for a related slowdown in the Atlantic meridional overturning circulation include a decrease in a range of proxies, including North Atlantic sea-surface temperature, deep ocean $\delta^{13} \mathrm{C}$, and precipitation, indicating a high sensitivity (Bauch et al., 2006; Galaasen et al., 2014; Irvali et al., 2012; Tzedakis et al., 2018).

In addition, there is some evidence for a reduction in Antarctic bottom water formation during the early part of the Last Interglacial $(\sim 127$ ka; Hayes et al., 2014). The exact timing and relationship between the changes in North Atlantic deep water and Antarctic bottom water is still unclear. One possibility is that an increase in the Southern Ocean heat content resulting from the early Last Interglacial Atlantic meridional overturning circulation slowdown (Stocker and Johnsen, 2003; Tzedakis et al., 2018) could have initiated a retreat of the Antarctic ice sheet. However, an initial meltwater discharge into the Southern Ocean would increase stratification, which could lead to a sub-surface warming that could further destabilise the Antarctic ice sheet (Menviel et al., 2010). A high-resolution record from the Portuguese margin, as well as a speleothem from Italy, further highlighted a series of multi-centennial Atlantic Meridional Overturning Circulation slowdowns throughout the Last Interglacial, indicating that the Last Interglacial was more climatically unstable than the Holocene (Tzedakis et al., 2018).

\subsection{Boreal forest}

The boreal forest zone is one of the planet's most important terrestrial carbon reservoirs (Bradshaw and Warkentin, 2015) and plays a large role in modulating surface albedo, reinforcing warming that can result in large climate sensitivity to radiation (Bonan, 2008). The boreal region is currently being rapidly altered as a result of a combination of climate change and other anthropogenic activities; the rate of these changes will determine the future health of this biome (Bradshaw et al., 2009; Reyer et al., 2015; Steffen et al., 2015). Today, and during the Last Interglacial, persistent high temperatures at the southern boreal forest limits could trigger temperature-induced drought stress on trees to the extent that net photosynthesis declines (D'Arrigo et al., 2004), while areas further north become suitable for boreal forest growth. While a detailed reconstruction of boreal forest extent during the Last Interglacial is hampered by poor chronological control in many areas (Lozhkin and Anderson, 1995), there are several 

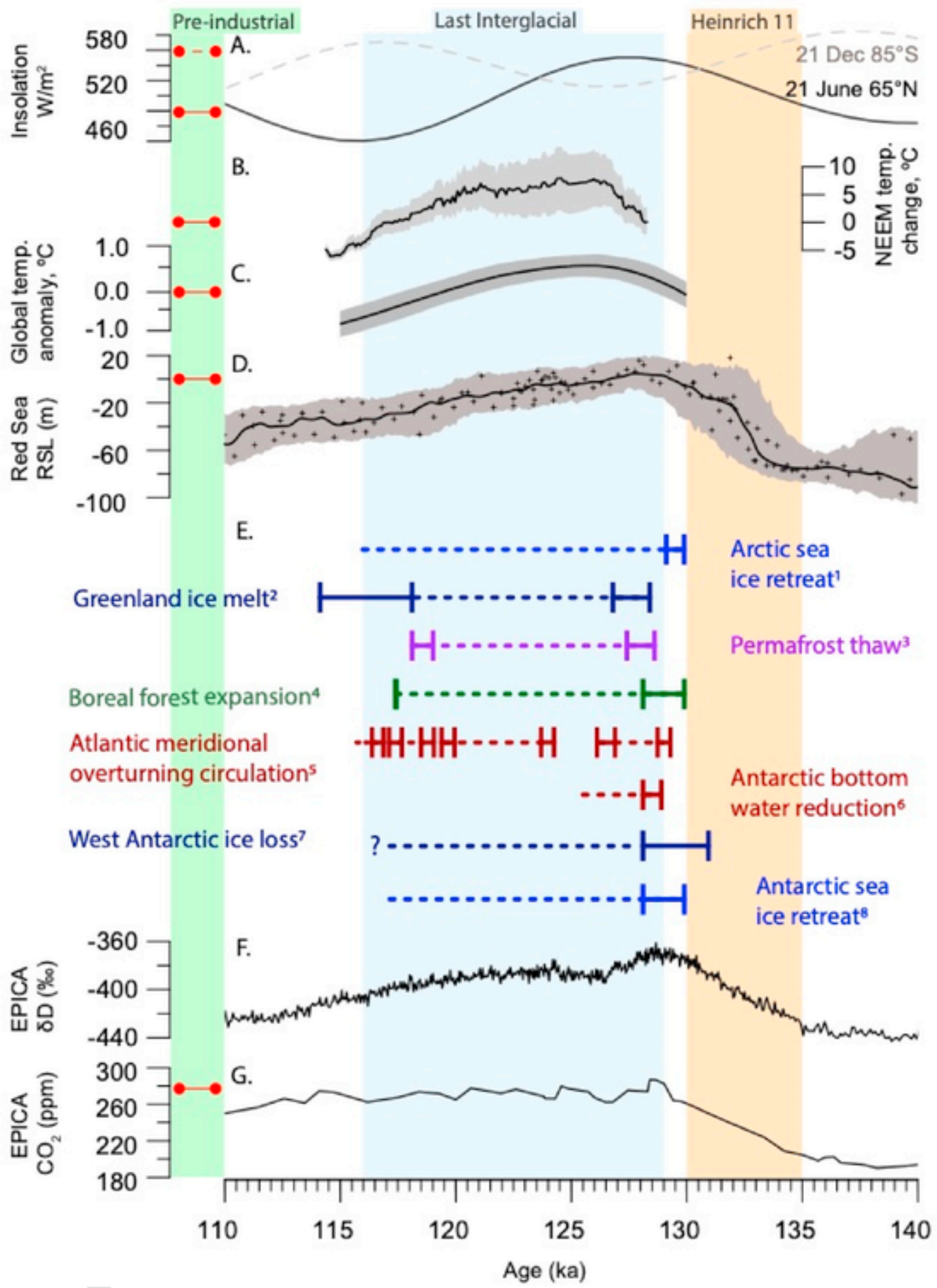

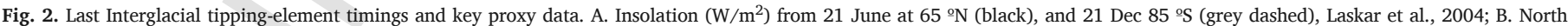

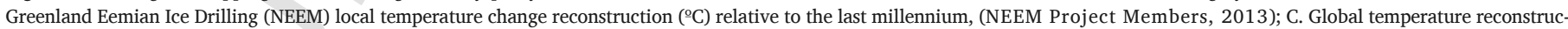

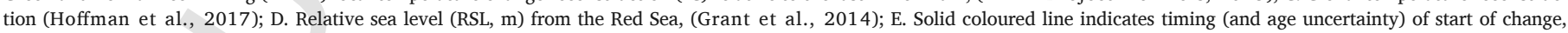

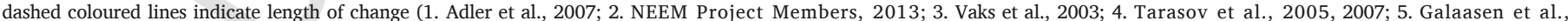

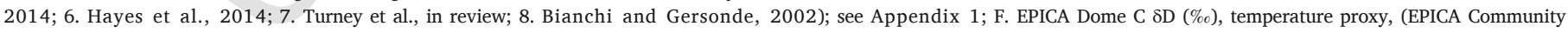

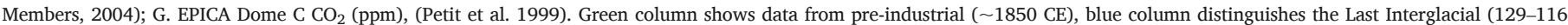
ka), and yellow column denotes Heinrich 11 (135-130 ka). Red horizontal lines within the green column denote the comparable pre-industrial levels for the proxy time-series. 
sites that allow insights into the range and species composition of the boreal forest at that time. For instance, palaeobotanical data from Russia and Scandinavia suggest that boreal-forest communities extended northwards by between 600 and $1000 \mathrm{~km}$ during the Last Interglacial (Lozhkin and Anderson, 1995; Saarnisto et al., 1999; Saarnisto and Lunkka, 2004), reaching the (current) northern coastline across the Northern Hemisphere in all areas except Alaska and central Canada (Otto-Bliesner et al., 2006). High-resolution magnetostratigraphy of Late Quaternary sediments from Lake Baikal in Siberia suggest that the tundra was replaced by boreal forest (taiga) by 128 ka (Demory et al., 2005; Tarasov et al., 2005), although no uncertainties on this estimate are reported.

The presence of Alaskan tephras provides an opportunity for the temporal comparison of records; for instance, evidence of spruce pollen and macrofossils from the high-elevation Alaska interior suggests an increase in altitude in the Last Interglacial treeline where tundra now exists (Muhs et al., 2001), with temporal control provided by the Old Crow tephra. Since this tephra layer is necessary to interpret the chronostratigraphy of the area, the tephra has been subjected to repeated redating. A glass fission-track age $(124 \pm 10 \mathrm{ka})$ still retained large uncertainties (Preece et al., 2011), preventing precise timing of the boreal-forest expansion. However, more recent redating (Burgess et al., 2019) using a zircon crystallisation technique has suggested that the tephra dates to $202.9 \pm 9.5 \mathrm{ka}$ within the Marine Isotope Stage 7 (MIS7) interglacial. This age differs from previous dating attempts, and also disagrees with existing stratigraphic chronologies from eastern Beringia, and has some far-reaching implications if it is indeed representative of the timing of Old Crow eruption. On balance, most evidence suggests expansion of boreal forests in the far north probably occurred in the early half of the Last Interglacial; however, questions remain regarding whether the rates of northward expansion matched the rate of southern edge retreat to higher latitudes, which ultimately determines whether the change was dominated by a latitudinal biome shift or decline in total area.

\subsection{Permafrost}

Permafrost is ground that remains colder than $0{ }^{\circ} \mathrm{C}$ for at least two consecutive years (Washburn, 1980), and currently constitutes a large carbon reservoir (containing $\sim 1672 \mathrm{Pg}$; Belshe et al., 2012). Increasing temperatures have the potential not only to increase carbon emissions from the thaw of previously frozen organic matter, but also to affect the carbon cycle indirectly through local and regional hydrological changes (Dutta et al., 2006; Lee et al., 2012; Neumann et al., 2019; Wagner et al., 2007); however, quantitative estimates are highly uncertain (Cooper et al., 2017; Walter Anthony et al., 2016). This 'thermokarst' process was a large carbon and methane emitter during past interglacials (Walter et al., 2007). Presence or absence of thermokarst features such as thaw-lake depressions (alases) and ice-wedge pseudomorphs (Wetterich et al., 2009) can be indicative of permafrost areas during the Last Interglacial (LIGA members et al., 1991; Reyes et al., 2010), although climatic interpretation of geomorphic features (Sher, 1991) can be unreliable. Similarly, vegetation reconstructions can estimate permafrost boundaries, with well-preserved plant macrofossils within both alases and pseudomorphs in north-eastern Siberia indicating extensive thawing during the Last Interglacial (Kienast et al., 2008).

Widespread lake formation in the Arctic lowlands of north-eastern Siberia and the Yukon have also been reported, but the chronology of the latter is imprecise (Andreev et al., 2004; Reyes et al., 2010). Cave speleothems have also been used to reconstruct millennial-scale changes in Siberian permafrost because speleothems cannot grow when the overlying soil is frozen (Vaks et al., 2013); speleothems found in modern permafrost areas are thus relics of a warmer past. Vaks et al. (2013) reported a north-south transect through several Siberian caves, and used precise U-series dating to show the initiation of speleothem growth at Botovskaya Cave, $55{ }^{\circ} \mathrm{N}$ (an area with sporadic permafrost today), at 128.7-127.3 ka, indicating early permafrost thawing due to high-latitude warming (Fig. 2). However, whether these regional changes are representative of the wider sub-Arctic region is debatable. Despite the presence of thermokarst erosion in Alaska and the Yukon, there are also several pre-Last Interglacial relict ice wedges stratigraphically beneath the (newly problematic) Old Crow tephra in the present discontinuous permafrost zone, indicating that permafrost thaw was not complete (Froese et al., 2008; Orlando et al., 2013; Reyes et al., 2010). In contrast to Siberia, no speleothem growth occurred during the Last Interglacial in the current permafrost zone in the Yukon (Lauriol et al., 1997), signifying a significant asymmetry in permafrost response to warming.

\section{Discussion}

\subsection{Do the data support a 'tipping cascade' during the Last Interglacial?}

The tipping elements described above all have rapid changes recorded by proxy evidence, suggesting threshold and/or non-linear behaviour during the Last Interglacial. A summary of key palaeo-proxy sites that provide information on one or more of the identified high-latitude tipping elements during the Last Interglacial can be found in Appendix 1. Arctic sea-ice retreat appears to be one of the first elements to have tipped, predating other large-scale changes in the Arctic with changes across the region recorded from before 130 ka (Adler et al., 2009). Robust evidence for and timing of Greenland ice-sheet mass loss from the North Greenland Eemian Ice Drilling core site is shortly after, at 128 ka (NEEM community members, 2013). Evidence of changes in the boreal biome and in permafrost extent appear to take place contemporaneously (within errors), with changes recorded at $\sim 128 \mathrm{ka}$. However, shifts of the latitudinal belt favouring the boreal forest could represent a linear response to temperature, although evidently the local transition from boreal forest to tundra is non-linear. More sites are needed to improve the spatial and temporal detail of these recorded changes. Although the insolation anomaly is symmetric about the Arctic, the Last Interglacial change in latitudinal extent of forest ecotones north of their northern-most Holocene limits appears to be most pronounced in Eurasia, but less so in Alaska and central and north-western Canada. In addition, the evidence for permafrost degradation is more pronounced in Siberia than the Yukon. Possible explanations for these asymmetries are likely related to the regional propagation of Arctic feedbacks (discussed in section 3.2).

In the south, recent evidence from the Patriot Hills blue ice area suggests that West Antarctic ice mass loss occurred early in the Last Interglacial, possibly as a result of Southern Ocean warming in response to a shutdown of the Atlantic meridional overturning circulation linked to Heinrich 11 (Marino et al., 2015; Turney et al., 2020). The retreat of the sea ice edge at a similar time $\sim 128 \mathrm{ka}$ (Bianchi and Gersonde, 2002; Holloway et al., 2016) might have played a role in the destabilisation of Antarctic ice shelves (such as the Filcher-Ronne). Importantly, the timing of substantially reduced North Atlantic deep water formation and increased iceberg-rafted debris from Greenland (Galaasen et al., 2014) is subsequent to identified Antarctic ice-sheet melt and reduction in Antarctic bottom water (Hayes et al., 2014; Turney et al., 2020). This suggests an important role of the bipolar seesaw during the Last Interglacial, in addition to ocean-atmosphere feedbacks in and between the polar regions (Cai et al., 2016; Marshall, 2013). Below, we explore some of the main feedback processes that occurred during the Last Interglacial to investigate how these interactions operated in the past, and provide some insights into how they might operate in the future (Fig. 3). 

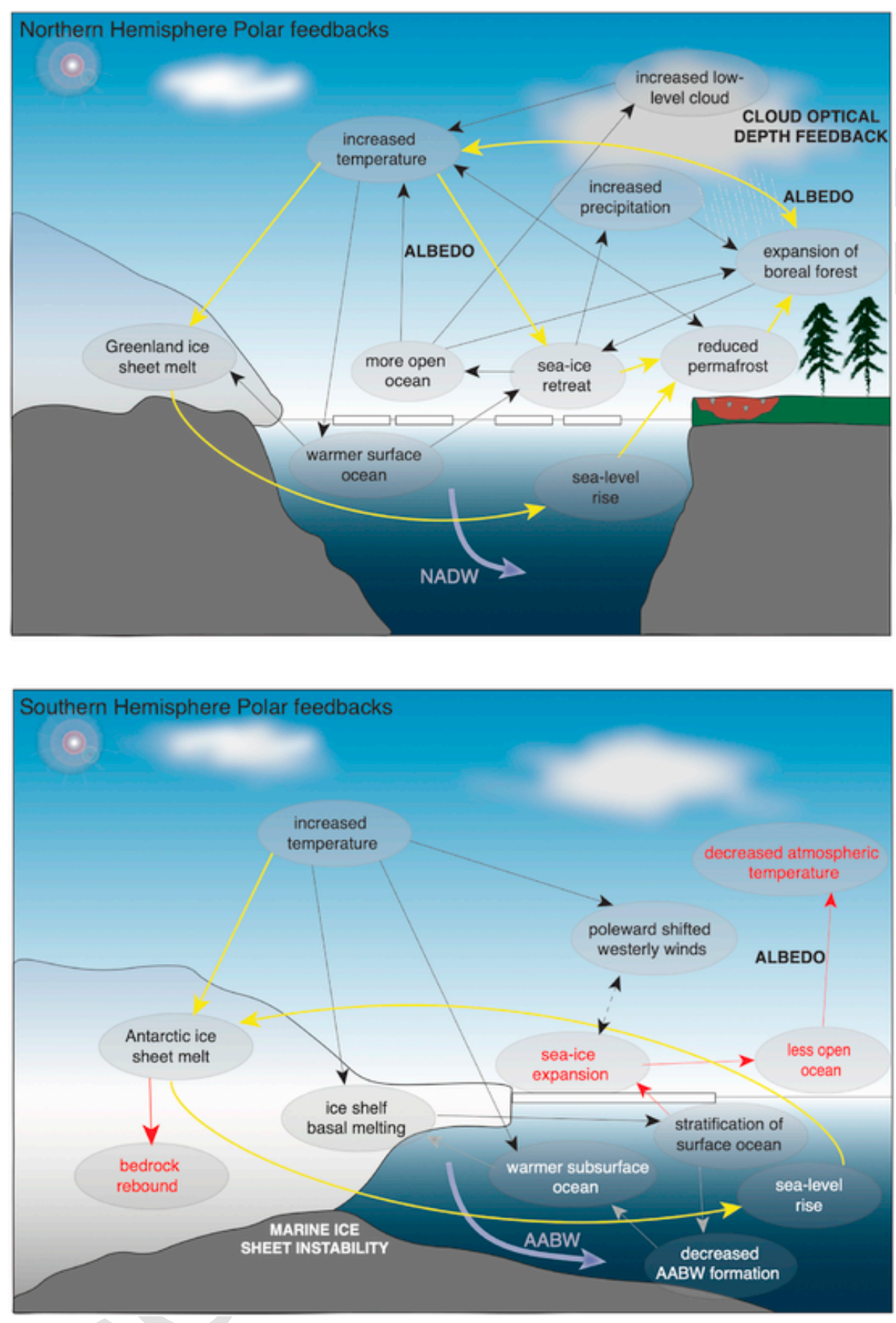

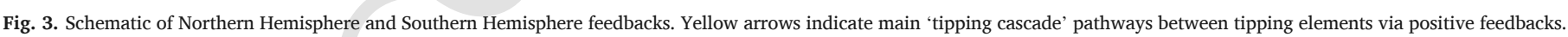

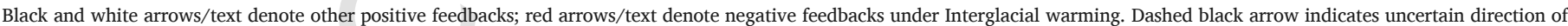
feedback (NADW: North Atlantic Deepwater; AABW: Antarctic Bottom Water).

\subsection{Northern Hemisphere feedbacks}

One of the most important Earth-system feedbacks is the positive ice-albedo feedback, where increased exposure of the dark ocean waters with a lower surface albedo following sea-ice melt causes increased absorption of solar radiation, enhancing surface melt (Fig. 3). New areas of open water can increase in temperature by up to $4-5{ }^{\circ} \mathrm{C}$ during summer, resulting in the delay in the onset of autumn sea-ice formation (Wadhams, 2012). Important feedbacks have been identified in Arctic sea ice where first-year ice grows more slowly and melts more rapidly, allowing increasingly larger areas of ice-free water in each subse- quent year (Wadhams, 2012). Thus, a potential tipping point can occur when the summer melt rate exceeds the winter growth rate such that multi-year ice cannot establish, and there is only seasonal ice cover (Eisenman and Wettlaufer, 2009; Wadhams, 2012). On the Greenland ice sheet, there are strong positive feedbacks related to albedo and elevation; as the ice sheet melts, local elevation decreases, effectively causing a rise in temperature of the surface. The ice-albedo feedback, including the effects of surface melt-ponds increasing the absorption of solar radiation (Schröder et al., 2014), further increases melting until a new equilibrium is reached. Other important radiative feedbacks in the Arctic result from a relatively large and positive lapse rate feedback (stable stratification suppresses vertical mixing, causing uneven warm- 
ing of the troposphere leading to a smaller increase in outgoing longwave radiation), positive water vapour feedback (amplifying the greenhouse effect) and a relatively weak and negative Planck response (Goosse et al., 2018). These feedbacks are stronger in the high northern latitudes than the high southern latitudes, explaining the strong observed Arctic amplification.

There are several important feedbacks through the Arctic hydrological cycle and changes in regional weather patterns (Cohen et al., 2014; Marshall, 2013). For example, since energetic wave events and storm events are expected to occur more frequently as the climate warms (Dall'Osto et al., 2017; Dobrynin et al., 2012), this has the potential to facilitate the break-up of sea ice by waves and ocean swells (Asplin et al., 2012). In addition, larger areas of open water in summer allow wind fetch sufficient to create waves, which can also accelerate the break-up of the ice edge (Wadhams, 2012), leading to further increases in wind fetch. Modelling suggests that the removal of Arctic sea ice can increase precipitation at high latitudes by up to $50 \%$ (Bintanja and Selten, 2014), with feedbacks affecting global climate through ice-mass balance as well as an increase in river discharge, affecting both global sea level and ocean circulation (Bracegirdle et al., 2015; Hobbs et al., 2016), with knock-on implications for terrestrial vegetation (Swann et al., 2010). Although the Arctic Ocean represents just $1 \%$ of global ocean volume, it receives an order of magnitude more freshwater runoff than the other oceans, meaning that the changing freshwater supply is an important determinant of its properties, e.g. salinity and buoyancy (Dai and Trenberth, 2002). The loss of perennial sea-ice cover in the Arctic influences the thermohaline circulation and regional climate in the sub-Arctic and North Atlantic (Notz, 2009). Freshwater anomalies from Greenland ice-sheet melt propagate into the Nordic seas, North Atlantic and beyond, enabling a change to the thermohaline structure that influences sea-ice coverage and thickness (Løwemark et al., 2016; Wadhams, 2012). Reduction of the thickness of sea ice can also increase heat flux from the ocean through reduced insulation of the thinner and/or absent ice (Gerdes, 2006). This also warms the shallow continental shelf, helping to melt offshore permafrost, in turn contributing to the release and decomposition of trapped methane hydrates (Wadhams, 2012). While a relationship between an ice-free Arctic and permafrost thaw has been established during interglacials prior to 400,000 years ago (Vaks et al., 2020), links during the Last Interglacial are less clear, possibly due to the presence of perennial/seasonal sea ice in the Western Arctic (Cronin et al., 2017). However, if the current trend towards reduced sea ice extent in the Arctic continues, the thawing of the Siberian permafrost is a likely candidate to join the tipping cascade.

The positive feedback between permafrost melting through ocean/ terrestrial warming and release of greenhouse gases via methane hydrates or decomposition of organic matter, as well as biochemical heat release associated with microbial decomposition, suggest that melting of the permafrost represents a tipping element. This is sometimes referred to as the 'compost-bomb instability' (Cox et al., 2000; Wieczorek et al., 2011) when the rate of local warming reaches a critical threshold. This strongly non-linear behaviour is due in part to the acceleration of permafrost melt when meltwater is drained in turn increasing oxygen availability for aerobic decomposition (Hollesen et al., 2015). In thermokarst lakes, a process known as 'ebullition' occurs, which is the release of methane from aquatic ecosystems as a result of permafrost melt on the lake margins (Walter et al., 2006). Disturbances such as fire, floods and vegetation succession can also accelerate permafrost degradation (Grosse et al., 2011). Sea level provides an additional important feedback to permafrost melt; intensified marine transgression can accelerate thermal erosion of the Siberian lowland permafrost (Kienast et al., 2008), potentially causing large amounts of trapped fossil carbon to be released (Walter et al., 2006). Evidence of such extensive thawing of coastal permafrost during the Last Interglacial is found in the Dmitry Laptev Strait (Wetterich et al., 2009). The Last Interglacial coastline was $\sim 400 \mathrm{~km}$ farther north than today as a result of tectonic spreading and subsidence (Kienast et al., 2008; Wetterich et al., 2016, 2009), resulting in a northward displacement of the polar front (CAPE, 2006) and increased continentality across the Laptev Sea shelf, accelerating permafrost melt through warmer summers and increased evaporation.

Permafrost degradation is one of several important feedback mechanisms that can occur within the boreal forest biome. Other feedbacks include albedo effects, carbon cycle storage/release, and changes in soil moisture and species composition. Specifically, feedback processes related to the biogeophysical properties of different vegetation types play an important role: dark boreal forests have a lower albedo, higher sensible heat flux and lower latent heat flux than tundra, largely due to the differences in leaf colour and canopy morphology (Lloyd et al., 2002). Replacement of tundra with 'darker' lower albedo boreal forest across the Arctic during the Last Interglacial would therefore have provided a strong positive feedback amplifying Arctic warming (Chapin, 2005; Serreze and Francis, 2006). In addition, the northward expansion of boreal forest is thought to have created a positive feedback for forest growth by reducing soil moisture loss through the increase in litter layer thickness and surface soil horizon depth (Muhs et al., 2001). Changes in climate can directly alter the species composition and/or range of the boreal forest, but also act indirectly through changing risk of wildfire, drought stress, and insect infestation (Bradshaw and Warkentin, 2015). A warming of the winter atmosphere from delayed winter sea ice formation, particularly along the Eurasian coast, could explain the expansion of the boreal forest far north of its present-day limit across Eurasia during the Last Interglacial (Cape Last Interglacial Project Members, 2006). Other consequences of the enhanced annual heat accumulation include the rapid degradation of permafrost, representing a complete positive feedback loop expected for a 'tipping cascade' (Lawrence et al., 2008).

\subsection{Southern hemisphere feedbacks}

Ice sheets contribute to global mean sea level rise through two main processes: surface/basal melting, and dynamic thinning (Golledge et al., 2015). While atmospheric thermal forcing and pressure melting can result in direct volume loss, dynamic thinning is more related to the large-scale adjustment of parts of an ice sheet as a result of increasing ice-flow speed (Golledge et al., 2015; Wouters et al., 2015). This can constitute an important non-linear response whereby the thinning continues until a new equilibrium is reached. In particular, dynamic thinning can be exacerbated if a glacier is grounded below sea level (and further promoted if the bed has an inverse slope) (DeConto and Pollard, 2016; Schoof, 2007). This is known as the 'marine ice sheet instability' (Fig. 3; Schoof, 2007), and constitutes an important hysteretic response, where even if thermal forcing ceases, dynamic thinning continues until a new dynamic equilibrium is reached, resulting in a lagged volumetric response (Schoof, 2007; Wouters et al., 2015). The West Antarctic Ice Sheet is a marine-based ice sheet with a largely inland-sloping bed and is thus highly sensitive to changes in sea level and ocean temperature, with (subsurface) ocean warming eroding the grounding line from below (Rignot et al., 2013). In fact, this subsurface warming poses a greater threat to Antarctic ice shelves and grounded ice than atmospheric warming (Golledge et al., 2015; Joughin et al., 2014; Payne et al., 2004). At the onset of the Last Interglacial, the retreat of the West Antarctic ice sheet is thought to have been driven mainly by ocean warming, although the amount of warming needed is contested (DeConto and Pollard, 2016; Sutter et al., 2016; Turney et al., 2020). Increased iceberg calving can result from ice-shelf thinning associated with increased ocean-driven basal melt (Liu et al., 2015), but is also linked to higher sea levels that 
can further destabilise the ice shelves that buttress major inland glaciers (Rintoul, 2018; Silvano et al., 2018). The potential for a marine ice-cliff instability to initiate runaway retreat after the collapse of a buttressing ice shelf (DeConto and Pollard, 2016) is an important feedback mechanism, but appears to be dependent on the timescale of ice shelf collapse (Clerc et al., 2019).

Model simulations indicate that a rapid collapse of the West Antarctic ice sheet led to a weakening of Antarctic bottom water formation (Menviel et al., 2010; Silvano et al., 2018). This resulted in warmer subsurface waters underneath the Ross Sea shelf and an intrusion of circumpolar deep water. This can further erode the grounding line of the West Antarctic ice sheet, accelerate melting, and increase the freshwater flux into the Southern Ocean, which provides a positive feedback for the further retreat of the ice sheet (Golledge et al., 2014; Menviel et al., 2010). However, ice-ocean feedbacks can be complex; basal melting can result in a cool and fresh surface layer of ocean water that creates a shield from the warmer, deeper waters driving this basal melting, thereby suppressing further melt of the ice shelf. This surface layer also enhances the formation of sea ice (Bintanja et al., 2013), which increases albedo. There are also complex interactions between atmospheric/oceanic warming, sea ice and the southern hemisphere westerly winds (Abram et al., 2014; Menviel et al., 2018; Thomas et al., 2018a). While cooler sea-surface temperatures are linked to changes in the southern annular mode due to an intensification and migration of the Southern Hemisphere westerlies (Marshall, 2003; Purich et al., 2016; Thomas et al., 2018b; Turney et al., 2016), models disagree on whether persistent westerly winds would increase or decrease sea-ice coverage around Antarctica. Earth-system climate models have shown that changes in the location of the Southern Hemisphere westerly winds could affect Southern Ocean circulation, which might consequently play a role in changing the mass balance of the Antarctic ice sheet (Fogwill et al., 2014). A further feedback related to sea ice is that decreased seasonal extent (which forms a protective buffer from ocean swells) enables increased wave-induced flexure of ice shelves (Massom et al., 2018). This was observed prior to the collapse of the Larsen A and B ice shelves, and likely played a role during the Last Interglacial when sea-ice extent was reduced.

Isostatic rebound can also constitute an important negative feedback to stabilise melting ice sheets (Fig. 3). This occurs when ice loss releases loading on the crust and mantle below, resulting in gradual uplift. The resultant increase in elevation of the ice sheet not only effectively decreases the surface temperature and slows melting, it can also potentially limit the effectiveness of the marine ice sheet instability (Barletta et al., 2018). This situation was suggested as a contributor during the early Holocene using parallel ice-sheet model (PISM) experiments where isostatic rebound could have halted ice retreat (Kingslake et al., 2018). However, model simulations from the Last Interglacial do not support the idea of a negative feedback resulting from isostatic uplift large enough to stabilise the West Antarctic ice sheet (Turney et al., 2020), because these models use a more realistic mantle viscosity $\left(10^{20} \mathrm{~Pa} / \mathrm{s}\right)$ than parameterisations by Kingslake et al. (2018). In addition, Feldmann and Levermann (2015) have suggested, using 5-km resolved parallel ice-sheet model simulations that if mass loss comparable to recent decades is maintained for as little as 60 years, the West Antarctic ice sheet could be irrevocably destabilised over subsequent millennia through the collapse in the Amundsen Sea sector, overcoming any moderating effect of isostatically driven rebound.

While the East Antarctic ice sheet is thought to be far more stable than the West Antarctic ice sheet, there are some marine-based sectors that increase its vulnerability to ocean warming (Fogwill et al., 2014), and local sea-level rise. For example, bathymetric surveys and radar sounding suggest the marine ice sheet instability might play an important future role in the further destabilisation of the Aurora subglacial basin through the Totten glacier, which is grounded below sea level and currently holds back an estimated $3.5 \mathrm{~m}$ of eustatic sea level potential (Greenbaum et al., 2015). Recent ice-sheet simulations suggest that the trigger for margin instability in some areas of the East Antarctic ice sheet can be thinning and surface lowering as a consequence of rising air temperatures, which ultimately facilitate margin flotation and rapid retreat, even in the absence of ocean warming (Golledge et al., 2017). Without ocean forcing, the timescale for this trigger is 1-2 millennia (with ocean forcing on the order of centuries), but once initiated results in abrupt retreat of hundreds of kilometres over centuries (Golledge et al., 2017).

Antarctica is influenced by other important feedbacks in addition to ice-ocean interactions. Sediments beneath the East and West Antarctic ice sheets constitute a generally neglected component of the global methane-hydrate inventory (Wadham et al., 2012). The predicted shallow depth of these reserves makes them particularly susceptible to climate forcing under scenarios of basal melt. While any methane release is mostly oxidised, there are large uncertainties surrounding the behaviour of methane hydrates under different climate scenarios (Wadham et al., 2012). In the ocean, benthic blue carbon strongly interacts with sea ice losses, acting as a negative feedback affecting global patterns (Peck et al., 2010). While the scouring of icebergs on the seabed is one of the largest limiters to the accumulation of blue-carbon (i.e. carbon stored in coastal and marine ecosystems) in benthic communities, the collapse of ice shelves opens up and generates productivity in vast new areas that were previously biologically unproductive, enabling major opportunities for benthic carbon capture and storage (Barnes et al., 2018). This drives a net gain of blue carbon, providing a negative feedback on climate warming. Giant icebergs leave a trail of nutrient enrichment, enhancing phytoplankton blooms in their path, so the potential magnitude of blue carbon capture depends on the timing and location of each iceberg's path, making calculation of carbon storage potential by this mechanism difficult. In fact, simulations show that a warming of Antarctic coastal waters of just one degree nearly doubles benthic growth, suggesting that this temperature-growth response could also constitute a negative feedback on climate (Ashton et al., 2017). It is possible that this negative feedback is an overlooked factor in explaining low carbon-dioxide concentrations during the Last Interglacial.

\subsection{Data-model comparisons}

The latest Paleoclimate Modelling Intercomparison Project phase 4 (Kageyama et al., 2018) timeslice experiments at 127,000 years ago (lig127k) display a strong warming at mid to high northern latitude during boreal summer, while simulating a cooling in boreal winter (Otto-Bliesner et al., 2020). This results in annual mean surface temperature differences between the Last Interglacial and pre-industrial of generally less than $1{ }^{\circ} \mathrm{C}$. In some regions, especially the high northern latitudes, models simulate consistent changes and agree with the sign of the proxy data, though not always the magnitude and rate, of Last Interglacial change (Lunt et al., 2013; Otto-Bliesner et al., 2013). In particular, model estimates of temperature changes over Greenland are lower than those reconstructed from ice cores, and largely fail to capture the extensive and early Last Interglacial warming recorded by the Antarctic ice cores. However, time-variant global circulation-model simulations show that the observed asynchronous hemispheric warming response can be replicated by including freshwater inputs to the North Atlantic from melting the remnant northern ice sheets during the deglaciation of marine isotope stage 6 (MIS 6; Capron et al., 2014; Masson-Delmotte et al., 2010; Otto-Bliesner et al., 2013; Stone et al., 2016). The limited implementation of polar tipping elements and feedbacks are often implicated in the data-model discrepan- 
cies during the Last Interglacial (Otto-Bliesner et al., 2013). Below we briefly compare palaeoclimate simulations with palaeodata specifically with regard to each of the polar tipping elements to explore the feedbacks that likely connected these sub-systems, and to identify future research priorities.

\subsubsection{Land-surface modelling}

Combined atmospheric and vegetation models are limited for the Last Interglacial; however, those that do exist largely support the palaeoenvironmental evidence of a northward-expanded boreal forest in northeast Siberia and Alaska during the Last Interglacial relative to the present (Harrison et al., 1995; Nikolova et al., 2013). But many Last Interglacial simulations assume modern vegetation structure (with tundra rather than boreal forest in the high northern latitudes), which has an impact on albedo and other connected feedbacks. Some model underestimation with respect to proxy-inferred warming could be a consequence of these missing vegetation feedbacks (Crucifix and Loutre, 2002; Schurgers et al., 2007). One of the difficulties in modelling future change arises through not incorporating feedback mechanisms. For example, the Intergovernmental Panel on Climate Change's Fifth Assessment Report suggested that Coupled Model Intercomparison Project 5 (CMIP5) models did not adequately account for greenhouse-gas emissions from thawing permafrost and the effects of the permafrost-carbon feedback on the global climate - the consequence of this is underestimating the probability of overshooting a $2{ }^{\circ} \mathrm{C}$ maximum warming target (Schaefer et al., 2014). In addition, only certain Earth-system models integrate important aspects such as smoke and dust through their subsequent effects on atmospheric chemistry and photosynthesis (Mitchard, 2018).

A possible explanation for the asymmetry observed from proxy records of boreal-forest expansion and permafrost degradation around the high, northern latitudes is the potential for increased flux of warm, Atlantic surface waters northward around the Eurasian Arctic (Matthiessen et al., 2001; Matthiessen and Knies, 2001). Atlantic water along the Arctic coast of Russia would have limited the formation of sea ice, minimising extreme winter cold, and thereby potentially promoting poleward expansion of evergreen trees. The flux of Atlantic water might also have influenced the climate by steering warm air masses into the Eurasian north (Cape Last Interglacial Project Members, 2006). In addition, warming during insolation maxima would have reduced the extent of permafrost areas, further facilitating expansion of the boreal forest. Multiple lines of evidence, including a high abundance of fern spores, and high chemical weathering of in situ palaeosols, suggest that precipitation was greater than present around Fairbanks, Alaska, during the peak of the Last Interglacial (Muhs et al., 2001). Correspondingly, a warmer and wetter climate promotes the growth and northward shift of boreal forest in two global climate models of different complexity (CCSM3 and LOVECLIM) (Nikolova et al., 2013). Similarly, within the framework of the lig127k PMIP4 experiments, proxy-based positive precipitation anomalies (producing 55\% more precipitation and 50\% more extreme precipitation) were found for the boreal regions (Scussolini et al., 2019).

\subsubsection{Modelling ocean-ice interactions}

Sea-ice reconstructions from the Northern Hemisphere are broadly consistent across two Earth-system models, one of intermediate complexity (LOVECLIM; Goosse et al., 2010) and one comprehensive atmosphere-ocean general circulation model (CCSM3; Collins et al., 2006). Both suggest reductions compared to pre-industrial of between 60 and $40 \%$ respectively, in the sea-ice and snow cover during the Last Interglacial (Lunt et al., 2013; Nikolova et al., 2013; Otto-Bliesner et al., 2006). The discrepancies between these models appear to be linked to feedbacks from sea ice and snow cover, with a weaker polar amplification simulated in CCSM3 than in LOVECLIM (Nikolova et al., 2013). An atmospheric general circulation model by Harrison et al. (1995) also simulates less-extensive, thinner Arctic Ocean sea ice derived from delayed sea-ice formation in autumn and earlier melting of sea ice in the spring. These results are consistent with high insolation values during the Last Interglacial contributing to early sea-ice melting in the summer season and a larger flux of warm Atlantic surface water early in the Last Interglacial (Cape Last Interglacial Project Members, 2006; Otto-Bliesner et al., 2006) (Fig. 2). In the Southern Hemisphere, there is a similarity between the forecasted Antarctic winter sea-ice reduction (up to $58 \%$ by the end of the 21 st Century) (IPCC, 2013) and the equivalent decrease suggested for the Last Interglacial (128 ka; 58-72\%) (Holloway et al., 2016), indicating that past changes could provide a useful framework for understanding future changes in sea ice.

While some estimates based on the combination of proxy-constrained climate and ice-sheet modelling suggest a contribution of between 2 and $3.4 \mathrm{~m}$ of sea level rise from Greenland (Otto-Bliesner et al., 2006), more recent model simulations constrained by glaciological data have indicated a lower contribution, with estimates instead of $1.6-2.2 \mathrm{~m}$ (Colville et al., 2011) and 0.3-3.6 m (with the most likely maximum at $1.5 \mathrm{~m}$ ) (Stone et al., 2013). The presence of ice at the North Greenland Eemian Ice Drilling site during the Last Interglacial can only be reconciled with simulations contributing up to $2 \mathrm{~m}$ of global sea level rise (NEEM community members, 2013), suggesting a greater contribution from Antarctica than previously thought. Most models simulate cool Antarctic summer temperatures, and little to no surface melt, with ocean warming as the major driver of ice sheet retreat. There is evidence from both palaeoclimate data and models for a major millennial/centennial-scale reorganisation of the Atlantic meridional overturning circulation during the Last Interglacial as a result of freshening surface waters in the high latitudes, and a cessation of North Atlantic deep water and Antarctic bottom water formation (Cape Last Interglacial Project Members, 2006; Carlson, 2008; Hayes et al., 2014; Tzedakis et al., 2018). Various ocean-melt temperature thresholds for ocean-driven warming of ice sheets have been proposed for the West Antarctic ice sheet and sub-basins therein. An ocean-melt threshold of $4{ }^{\circ} \mathrm{C}$ was proposed to destabilise the Thwaites glacier grounding line (DeConto and Pollard, 2016), although this decreases to $3{ }^{\circ} \mathrm{C}$ with the addition of ocean warming on the atmosphere. In contrast, ocean warming thresholds of $2-3{ }^{\circ} \mathrm{C}$ (Sutter et al., 2016) and $2{ }^{\circ} \mathrm{C}$ (Turney et al., 2020), are considered sufficient for substantial retreat of the West Antarctic ice Sheet, accounting for a sea level rise on the order of 3-4 m. Various modelled scenarios including 'ice plug' removal (Mengel and Levermann, 2014), ice-shelf hydrofracture, and ice-cliff failure (Pollard et al., 2015) represent attempts to capture the non-linear mechanisms that allow rapid ice-sheet collapse (DeConto and Pollard, 2016); however, the physical basis of these scenarios is not fully resolved (Clerc et al., 2019; Edwards et al., 2019). Given that ice-sheet response depends on these non-linear mechanisms, exploring these controls is essential to understand the propagation of feedbacks in the polar regions.

\section{Conclusions and research priorities}

Palaeoclimate reconstructions from the Last Interglacial provide a powerful opportunity to obtain insights into the drivers of past and future change at high latitudes. A wealth of ice, terrestrial, and marine records indicate that large-scale shifts in state took place, that were not reversible on millennial timescales. The forcings behind these changes appear to have been small, implying specific thresholds, or 'tipping points' were triggered (reached by self-reinforcing feedbacks), driving extreme, nonlinear changes across the polar regions. The expert elicitation of Steffen et al., (2019) suggests future destabilising temperature thresholds of Earth System tipping elements to range between 1 and $5{ }^{\circ} \mathrm{C}$ warming, but these thresholds are based on global averages and 
do not appear to take into account amplifying feedbacks in the polar regions. Our synthesis illustrates a tight interconnection between polar tipping elements such that similar thresholds of vulnerability are likely in the future. While this synthesis shows that these tipping elements all responded early in the Last Interglacial, based on the current chronological frameworks for these records, it is not yet possible to determine accurately any leads and lags on the timescales of 1-2 millennia or below. Further resolving the timelines of change for many tipping elements is problematic because of limited dating control in marine, terrestrial, and ice records. We recommend the following research priorities, complementing those identified by Capron et al. (2019) to elucidate these complex climate processes:

- Enhancing the chronological control of proxy records will provide a more complete understanding of leads and lags in the climate system. One of the best ways to do this is to develop a comprehensive tephrochronology for the polar regions, which will identify time-parallel marker horizons from which to analyse leads and lags on sub-millennial timescales.

- Developing a more comprehensive network of marine, ice, and terrestrial records globally that are well-dated, integrated, and publicly available. In particular, a priority could be multi-proxy analysis of near-shore marine sediments to permit detailed land-sea correlations (for example, via high-resolution pollen analysis with reconstruction of sea-surface temperatures).

- Exploring new proxies of environmental change, such as ancient DNA in marine and ice sediments that can potentially provide direct ocean-ice correlations.

- Developing a more complete physical understanding of the non-linear mechanisms driving ice sheet retreat - this could be assisted by more detailed reconstructions of sea-surface temperatures from the Last Interglacial (from both new and legacy/archived marine cores) from which to inform ice-sheet model forcings.

- Obtaining closer integration of the modelling and proxy development communities to resolve data-model discrepancies and quantify polar feedbacks during the Last Interglacial and in the future. This urgently requires palaeoclimate data to construct realistic boundary conditions for ice-sheet models.

Integrating ice, terrestrial, and marine reconstructions with state-of-the-art ice-sheet and climate models will help to account for mechanisms and triggers that could potentially give rise to abrupt changes and tipping points. Using the Last Interglacial as a "process analogue' for future change provides major insights into the broader drivers and impacts of abrupt shifts during past periods with warmer-than-present-day conditions. While past periods are not completely faithful analogues for anthropogenic-driven climate change, quantifying and documenting regional changes during the Last Interglacial can help to anticipate future changes in important tipping elements that could have global implications for predicting the timing and magnitude of potential cascades.

\section{Acknowledgements}

We acknowledge the contribution of our close friend and colleague, Richard Jones, without whom this work would not have been possible. He is dearly missed. CSMT, CJF, MIB, LM and NRG are supported by their respective Australian Research Council (ARC) and Royal Society of New Zealand fellowships. This is a contribution to the Earth's Past Future network (earthspastfuture.com). This research was supported by Australian Research Council (ARC) Centre of Excellence for Australian Biodiversity and Heritage (EpicAustralia.org.au).

\section{Appendix A. Supplementary data}

Supplementary data to this article can be found online at https://doi. org/10.1016/j.quascirev.2020.106222.

\section{References}

Abram, N.J., Mulvaney, R., Vimeux, F., Phipps, S.J., Turner, J., England, M.H., 2014. Evolution of the southern annular mode during the past millennium. Nat. Clim. Change 4, 1-6. doi:10.1038/NCLIMATE2235.

Adler, R.E., Polyak, L., Ortiz, J.D., Kaufman, D.S., Channell, J.E.T., Xuan, C., Grottoli, A.G., Sellén, E., Crawford, K.A., 2009. Sediment record from the western Arctic Ocean with an improved late quaternary age resolution: HOTRAX core HLY0503-8JPC, Mendeleev ridge. Global Planet. Change 68, 18-29. doi:10.1016/j.gloplacha.2009.03.026.

Alley, R.B., Marotzke, J., Nordhaus, W.D., Overpeck, J.T., Peteet, D.M., Pielke, R. a, Pierrehumbert, R.T., Rhines, P.B., Stocker, T.F., Talley, L.D., Wallace, J.M., 2003. Abrupt climate change. Science 299. 2005-10. doi:10.1126/science.1081056.

Andreev, A.A., Grosse, G., Schirrmeister, L., Kuzmina, S.A., Novenko, E.Y., Bobrov, A.A. Tarasov, P.E., Ilyashuk, B.P., Kuznetsova, T.V., Krbetschek, M., Meyer, H., Kunitsky, V.V., 2004. Late Saalian and Eemian palaeoenvironmental history of the Bol'shoy Lyakhovsky Island (Laptev Sea region, arctic Siberia). Boreas 33, 319-348. doi:10.1111/j.1502-3885.2004.tb01244.x.

Ashton, G.V., Morley, S.A., Barnes, D.K.A., Clark, M.S., Peck, L.S., 2017. Warming by $1^{\circ} \mathrm{C}$ drives species and assemblage level responses in Antarctica's marine shallows. Curr. Biol. 27, 2698-2705. e3. doi:10.1016/j.cub.2017.07.048.

Asplin, M.G., Galley, R., Barber, D.G., Prinsenberg, S., 2012. Fracture of summer perennial sea ice by ocean swell as a result of Arctic storms. J. Geophys. Res. Ocean. 117, 1-12. doi:10.1029/2011JC007221.

Austermann, J., Mitrovica, J.X., Huybers, P., Rovere, A., 2017. Detection of a dynamic topography signal in last interglacial sea-level records. Sci. Adv. 3, e1700457. doi:10.1126/sciadv.1700457.

Bamber, J.L., Riva, R.E.M., Vermeersen, B.L.A., LeBrocq, A.M., 2009. Reassessment of the potential Sea-level rise from a collapse of the west Antarctic ice sheet. Science 901, 901-904. doi:10.1126/science.1169335.

Barletta, V.R., Khan, S.A., Rovira-Navarro, M., Bevis, M., Wilson, T., Brown, A., Kendrick, E., Konfal, S., Caccamise, D.J., Smith, B.E., Bordoni, A., Willis, M., Dalziel, I., Smalley, R., Aster, R.C., Nyblade, A., Wiens, D.A., 2018. Observed rapid bedrock uplift in amundsen sea embayment promotes ice-sheet stability. Science 360, 1335-1339. doi:10.1126/science.aao1447.

Barnes, D.K.A., Fleming, A., Sands, C.J., Quartino, M.L., Deregibus, D., 2018. Icebergs, sea ice, blue carbon and Antarctic climate feedbacks. Philos. Trans. R. Soc. London A Math. Phys. Eng. Sci. 376. doi:10.1098/rsta.2017.0176.

Bauch, H.A., Kandiano, E.S., Helmke, J., Andersen, N., Rosell-mele, A., 2006. Climatic bisection of the last interglacial warm period in the Polar North Atlantic. Quat. Sci. Rev. 30, 1813-1818. doi:10.1016/j.quascirev.2011.05.012.

Belshe, E.F., Schuur, E.A.G., Bolker, B.M., Bracho, R., 2012. Incorporating spatial heterogeneity created by permafrost thaw into a landscape carbon estimate. J. Geophys. Res. Biogeosciences 117, 1-14. doi:10.1029/2011JG001836.

Bevis, M., Harig, C., Khan, S.A., Brown, A., Simons, F.J., Willis, M., Fettweis, X., Broeke, M.R. van den, Madsen, F.B., Kendrick, E., Caccamise, D.J., Dam, T. van, Knudsen, P., Nylen, T., 2019. Accelerating changes in ice mass within Greenland, and the ice sheet's sensitivity to atmospheric forcing. Proc. Natl. Acad. Sci. 201806562. doi:10.1073/PNAS.1806562116.

Bianchi, C., Gersonde, R., 2002. The Southern Ocean surface between marine isotope stages 6 and 5d: shape and timing of climate changes. Palaeoceanography 187, 151-177.

Bintanja, R., Selten, F.M., 2014. Future increases in Arctic precipitation linked to local evaporation and sea-ice retreat. Nature 509, 479-482. doi:10.1038/nature13259.

Bintanja, R., van Oldenborgh, G.J., Drijfhout, S.S., Wouters, B., Katsman, C.A., 2013. Important role for ocean warming and increased ice-shelf melt in Antarctic sea-ice expansion. Nat. Geosci. 6, 376-379. doi:10.1038/ngeo1767.

Bonan, G.B., 2008. Forests and climate change: forcings, feedbacks, and the climate benefits of forests. Science 1444, 1155121. doi:10.1126/science.1155121.

Bracegirdle, T.J., Stephenson, D.B., Turner, J., Phillips, T., 2015. The importance of sea-ice area biases in 21 st century multi-model projections of Antarctic temperature and precipitation. Geophys. Res. Lett. n/a-n/a. doi:10.1002/2015GL067055.

Bracegirdle, C., Abram, B., Dixon, E., Favier, F., Fyfe, G., Goosse, H., Jones, K., Khan, P., Raphael, R., Sime, T., van den Broeke, W., 2019. Back to the future: using long-term observational and paleo-proxy reconstructions to improve model projections of Antarctic climate. Geosciences 9, 255. doi:10.3390/geosciences9060255.

Braconnot, P., Harrison, S.P., Kageyama, M., Bartlein, P.J., Masson-delmotte, V., Abe-ouchi, A., Otto-bliesner, B., Zhao, Y., 2012. Evaluation of climate models using palaeoclimatic data. Nat. Clim. Change 2, 417-424. doi:10.1038/nclimate1456.

Bradshaw, C.J.A., Warkentin, I.G., 2015. Global estimates of boreal forest carbon stocks and flux. Global Planet. Change 128, 24-30. doi:10.1016/j.gloplacha.2015.02.004.

Bradshaw, C.J.A., Warkentin, I.G., Sodhi, N.S., 2009. Urgent preservation of boreal carbon stocks and biodiversity. Trends Ecol. Evol. 24, 541-548. doi:10.1016/ j.tree.2009.03.019.

Brigham-Grette, J., Hopkins, D., 1995. Emergent marine record and paleoclimate of the last interglaciation along the northwest Alaskan coast. Quat. Res. 43, 159-173.

Brigham-Grette, J., Hopkins, D.M., Ivanov, V.F., Basilyan, A.E., Benson, S.L., Heiser, P.A., Pushkar, V.S., 2001. Last interglacial (isotope stage 5) glacial and sea-level history of coastal Chukotka Peninsula and St. Lawrence Island, Western Beringia. Quat. Sci. Rev. 20, 419-436. doi:10.1016/S0277-3791(00)00107-4. 
Bronselaer, B., Winton, M., Griffies, S.M., Hurlin, W.J., Rodgers, K.B., Sergienko, O.V., Stouffer, R.J., Russell, J.L., 2018. Change in future climate due to Antarctic meltwater. Nature doi:10.1038/s41586-018-0712-z.

Burgess, S.D., Coble, M.A., Vazquez, J.A., Coombs, M.L., Wallace, K.L., 2019. On the eruption age and provenance of the Old Crow tephra. Quat. Sci. Rev. 207, 64-79. doi:10.1016/j.quascirev.2018.12.026.

Caesar, L., Rahmstorf, S., Robinson, A., Feulner, G., Saba, V., 2018. Observed fingerprint of a weakening Atlantic Ocean overturning circulation. Nature 556, 1-19. doi:10.1038/ s41586-018-0006-5.

Cai, Y., Lenton, T.M., Lontzek, T.S., 2016. Risk of multiple interacting tipping points should encourage rapid CO2 emission reduction. Nat. Clim. Change doi:10.1038/ nclimate2964.

Cape Last Interglacial Project Members, 2006. Last Interglacial Arctic warmth confirms polar amplification of climate change. Quat. Sci. Rev. 25, 1383-1400. doi:10.1016/ j.quascirev.2006.01.033.

Capron, E., Govin, A., Stone, E.J., Mulitza, S., Otto-bliesner, B., Rasmussen, T.L., Sime, L.C., Waelbroeck, C., Wolff, E.W., 2014. Temporal and spatial structure of multi-millennial temperature changes at high latitudes during the Last Interglacial. Quat. Sci. Rev. 103, 116-133. doi:10.1016/j.quascirev.2014.08.018.

Capron, E., Govin, A., Feng, R., Otto-Bliesner, B.L., Wolff, E.W., 2017. Critical evaluation of climate syntheses to benchmark CMIP6/PMIP4 127 ka Last Interglacial simulations in the high-latitude regions. Quat. Sci. Rev. 168, 137-150. doi:10.1016/ j.quascirev.2017.04.019.

Capron, E., Rovere, A., Austermann, J., Axford, Y., Barlow, N.L.M., Carlson, A.E., de Vernal, A., Dutton, A., Kopp, R.E., McManus, J.F., Menviel, L., Otto-Bliesner, B.L., Robinson, A., Shakun, J.D., Tzedakis, P.C., Wolff, E.W., 2019. Challenges and research priorities to understand interactions between climate, ice sheets and global mean sea level during past interglacials. Quat. Sci. Rev. doi:10.1016/j.quascirev.2019.06.030.

Carlson, A.E., 2008. Why there was not a younger Dryas-like event during the penultimate deglaciation. Quat. Sci. Rev. 27, 882-887. doi:10.1016/j.quascirev.2008.02.004.

Church, J.A., Clark, P.U., Cazenave, A., Gregory, J.M., Jevrejeva, S., Levermann, A., Merrifield, M.A., Milne, G.A., Nerem, R., Nunn, P.D., Payne, A.J., Pfeffer, W.T., Stammer, D., Unnikrishnan, A.S., 2013. Sea level change. In: Clim. Chang. 2013 Phys. Sci. Basis. Contrib. Work. Gr. I to Fifth Assess. Rep. Intergov. Panel Clim. Chang.. pp. 1137-1216. doi:10.1017/CB09781107415315.026.

Clark, P.U., Huybers, P., 2009. Global change: interglacial and future sea level. Nature 462, 856-857. doi:10.1029/2009GL040222.

Clerc, F., Minchew, B.M., Behn, M.D., 2019. Marine ice cliff instability mitigated by slow removal of ice shelves. Geophys. Res. Lett. doi:10.1029/2019GL084183.

Cohen, J., Screen, J.A., Furtado, J.C., Barlow, M., Whittleston, D., Coumou, D., Francis, J., Dethloff, K., Entekhabi, D., Overland, J., Jones, J., 2014. Recent Arctic amplification and extreme mid-latitude weather. Nat. Geosci. 7, 627-637. doi:10.1038/ngeo2234.

Collins, W.D., Blackmon, M.L., Bonan, G.B., Hack, J.J., Henderson, T.B., Kiehl, J.T., Large, W.G., McKenna, D.S., 2006. The community climate system model version 3 (CCSM3). J. Clim. 19, 2122-2143.

Collins, M., Knutti, R., Arblaster, J., Dufresne, J.L., Fichefet, T., Friedlingstein, P., Gao, X., Gutowski, W.J., Johns, T., Krinner, G., Shongwe, M., Tebaldi, C., Weaver, A.J., Wehner, M., 2013. Long-term climate change: projections, commitments and irreversibility. In: Stocker, T., Qin, D., Plattner, G.-K., Tignor, M., Allen, S., Boschung, J., Nauels, A., Xia, Y., Bex, V., Midgley, P.M. (Eds.), Climate Change 2013: the Physical Science Basis. Contribution Of Working Group I to the Fifth Assessment Report of the Intergovernmental Panel on Climate Change. Cambridge University Press, pp. 1029-1136.

Colville, E.J., Carlson, A.E., Beard, B.L., Hatfield, R.G., Stoner, J.S., Reyes, A.V., Ullman, D.J., 2011. Sr-Nd-Pb isotope evidence for ice-sheet presence on southern Greenland during the last interglacial. Science 333, 620-623. doi:10.1126/science.1204673.

Cooper, M.D.A., Estop-Aragonés, C., Fisher, J.P., Thierry, A., Garnett, M.H., Charman, D.J., Murton, J.B., Phoenix, G.K., Treharne, R., Kokelj, S.V., Wolfe, S.A., Lewkowicz, A.G., Williams, M., Hartley, I.P., 2017. Limited contribution of permafrost carbon to methane release from thawing peatlands. Nat. Clim. Change 7, 507-511. doi:10.1038/ nclimate3328.

Cox, P.M., Betts, R. a, Jones, C.D., Spall, S. a, Totterdell, I.J., 2000. Acceleration of global warming due to carbon-cycle feedbacks in a coupled climate model (vol 408, pg 184, 2000). Nature 408, 750. doi:10.1038/35041539.

Cronin, T.M., Dwyer, G.S., Caverly, E.K., Farmer, J., DeNinno, L.H., Rodriguez-Lazaro, J., Gemery, L., 2017. Enhanced arctic amplification began at the mid-brunhes event $\sim 400,000$ years ago. Sci. Rep. 7, 1-7. doi:10.1038/s41598-017-13821-2.

Crucifix, M., Loutre, M.F., 2002. Transient simulations over the last interglacial period (126- 115 kyr BP): feedback and forcing analysis. Clim. Dynam. 19, 417-433. doi:10.1007/s00382-002-0234-z.

Dai, A., Trenberth, K.E., 2002. Estimates of freshwater discharge from Continents : latitudinal and seasonal variations. J. Hydrometeorol. 3, 660-687.

Dakos, V., Scheffer, M., van Nes, E.H., Brovkin, V., Petoukhov, V., Held, H., 2008. Slowing down as an early warning signal for abrupt climate change. Proc. Natl. Acad. Sci. U.S.A. 105, 14308-14312. doi:10.1073/pnas.0802430105.

Dakos, V., Carpenter, S.R., van Nes, E.H., Scheffer, M., 2014. Resilience indicators: prospects and limitations for early warnings of regime shifts. Philos. Trans. R. Soc. B Biol. Sci. 370, 20130263. doi:10.1098/rstb.2013.0263.

Dall'Osto, M., Ovadnevaite, J., Paglione, M., Beddows, D.C.S., Ceburnis, D., Cree, C., Cortés, P., Zamanillo, M., Nunes, S.O., Pérez, G.L., Ortega-Retuerta, E., Emelianov, M., Vaqué, D., Marrasé, C., Estrada, M., Sala, M.M., Vidal, M., Fitzsimons, M.F., Beale, R., Airs, R., Rinaldi, M., Decesari, S., Facchini, M.C., Harrison, R.M., O’Dowd, C., Simó, R., 2017. Antarctic sea ice region as a source of biogenic organic nitrogen in aerosols. Sci. Rep. 7, 1-10. doi:10.1038/s41598-017-06188-x.

Dangendorf, S., Hay, C., Calafat, F.M., Marcos, M., Piecuch, C.G., Berk, K., Jensen, J., 2019. Persistent acceleration in global sea-level rise since the 1960s. Nat. Clim. Change doi:10.1038/s41558-019-0531-8.
DeConto, R.M., Pollard, D., 2016. Contribution of Antarctica to past and future sea-level rise. Nature 531, 591-597. doi:10.1038/nature17145.

Demory, F., Nowaczyk, N.R., Witt, A., Oberhänsli, H., 2005. High-resolution magnetostratigraphy of late quaternary sediments from Lake Baikal, Siberia: timing of intracontinental paleoclimatic responses. Global Planet. Change 46, 167-186. doi:10.1016/j.gloplacha.2004.09.016.

Dobrynin, M., Murawsky, J., Yang, S., 2012. Evolution of the global wind wave climate in CMIP5 experiments. Geophys. Res. Lett. 39, 2-7. doi:10.1029/2012GL052843.

Drijfhout, S., Bathiany, S., Beaulieu, C., Brovkin, V., Claussen, M., Huntingford, C., Scheffer, M., Sgubin, G., Swingedouw, D., 2015. Catalogue of abrupt shifts in intergovernmental Panel on climate change climate models. Proc. Natl. Acad. Sci. 112, E5777-E5786. doi:10.1073/pnas.1511451112.

Dutta, K., Schuur, E.A.G., Neff, J.C., Zimov, S.A., 2006. Potential carbon release from permafrost soils of Northeastern Siberia. Global Change Biol. 12, 2336-2351. doi:10.1111/j.1365-2486.2006.01259.x.

Dutton, A., Carlson, A.E., Long, A.J., Milne, G.A., Clark, P.U., DeConto, R., Horton, B.P., Rahmstorf, S., Raymo, M.E., 2015. Sea-level rise due to polar ice-sheet mass loss during past warm periods. Science 349. aaa4019-aaa4019. doi:10.1126/science.aaa4019.

D’Arrigo, R.D., Kaufmann, R.K., Davi, N., Jacoby, G.C., Laskowski, C., Myneni, R.B., Cherubini, P., 2004. Thresholds for warming-induced growth decline at elevational tree line in the Yukon Territory, Canada. Global Biogeochem. Cycles 18, 1-7. doi:10.1029/2004GB002249.

Edwards, T.L., Brandon, M., Durand, G., Edwards, N.R., Golledge, N.R., Holden, P.B., Nias, I., Payne, A., Ritz, C., 2019. Revisiting Antarctic ice loss due to marine ice cliff instability. Nature 566, 58-64. doi:10.1038/s41586-019-0901-4.

Eisenman, I., Wettlaufer, J.S., 2009. Nonlinear threshold behavior during the loss of Arctic sea ice. Proc. Natl. Acad. Sci. U.S.A. 106, 28-32. doi:10.1073/pnas.0806887106.

Fischer, H., Fundel, F., Ruth, U., Twarloh, B., Wegner, A., Udisti, R., Becagli, S., Castellano, E., Morganti, A., Severi, M., Wolff, E., Littot, G., Röthlisberger, R., Mulvaney, R., Hutterli, M.A., Kaufmann, P., Federer, U., Lambert, F., Bigler, M., Boutron, C., Siggaard-andersen, M., Gaspari, V., Gabrielli, P., Wagenbach, D., 2007. Reconstruction of millennial changes in dust emission, transport and regional sea ice coverage using the deep EPICA ice cores from the Atlantic and Indian Ocean sector of Antarctica. Earth Planet Sci. Lett. 260, 340-354. doi:10.1016/j.epsl.2007.06.014.

Fogwill, C.J., Hein, A.S., Bentley, M.J., Sugden, D.E., 2012. Do blue-ice moraines in the Heritage Range show the West Antarctic ice sheet survived the last interglacial? Palaeogeogr. Palaeoclimatol. Palaeoecol. 335-336, 61-70. doi:10.1016/ j.palaeo.2011.01.027.

Fogwill, C.J., Turney, C.S.M., Meissner, K.J., Golledge, N.R., Spence, P., Roberts, J.L., England, M.H., Jones, R.T., Carter, L., 2014. Testing the sensitivity of the East Antarctic ice sheet to Southern Ocean dynamics: past changes and future implications. J. Quat. Sci. 29, 91-98. doi:10.1002/jqs.2683.

Fretwell, P., Pritchard, H.D., Vaughan, D.G., Bamber, J.L., Barrand, N.E., Bell, R., Bianchi, C., Bingham, R.G., Blankenship, D.D., Casassa, G., Catania, G., Callens, D., Conway, H., Cook, A.J., Corr, H.F.J., Damaske, D., Damm, V., Ferraccioli, F., Forsberg, R., Fujita, S., Gim, Y., Gogineni, P., Griggs, J.A., Hindmarsh, R.C.A., Holmlund, P., Holt, J.W., Jacobel, R.W., Jenkins, A., Jokat, W., Jordan, T., King, E.C., Kohler, J., Krabill, W., Riger-Kusk, M., Langley, K.A., Leitchenkov, G., Leuschen, C., Luyendyk, B.P. Matsuoka, K., Mouginot, J., Nitsche, F.O., Nogi, Y., Nost, O.A., Popov, S.V., Rignot, E., Rippin, D.M., Rivera, A., Roberts, J., Ross, N., Siegert, M.J., Smith, A.M., Steinhage, D., Studinger, M., Sun, B., Tinto, K., B., Welch, C., B., Wilson, D., Young, D.A., Xiangbin, C., Zirizzotti, A., 2013. Bedmap2: improved ice bed, surface and thickness datasets for Antarctica. Cryosphere 7, 375-393.

Froese, D.G., Westgate, J.A., Reyes, A.V., Enkin, R.J., Preece, S.J., 2008. Ancient permafrost and a future, warmer arctic. Science 321, 1648. doi:10.1126/ science. 1157525

Galaasen, E.V., Ninnemann, U.S., Irvalı, N., Kleiven, H.K.F., Rosenthal, Y., Kissel, C., Hodell, D.A., 2014. Rapid reductions in north atlantic deep water during the peak of the last interglaical period. Science 343, 1129-1132. doi:10.1126/science.1248667.

Gerdes, R., 2006. Atmospheric response to changes in Arctic sea ice thickness. Geophys. Res. Lett. 33, 1-4. doi:10.1029/2006GL027146.

Golledge, N.R., Menviel, L., Carter, L., Fogwill, C.J., England, M.H., Cortese, G., Levy, R.H., 2014. Antarctic contribution to meltwater pulse $1 \mathrm{~A}$ from reduced Southern Ocean overturning. Nat. Commun. 5, 5107. doi:10.1038/ncomms6107.

Golledge, N.R., Kowalewski, D.E., Naish, T.R., Levy, R.H., Fogwill, C.J., Gasson, E.G.W., 2015. The multi-millennial Antarctic commitment to future sea-level rise. Nature 526, 421-425. doi:10.1038/nature15706.

Golledge, N.R., Thomas, Z.A., Levy, R.H., Gasson, E.G.W., Naish, T.R., Mckay, R.M., Kowalewski, D.E., Fogwill, C.J., 2017. Antarctic climate and ice-sheet configuration during the early Pliocene interglacial at $4.23 \mathrm{Ma}$. Clim. Past 13, 959-975. doi:10.5194/cp-13-959-2017.

Golledge, N.R., Keller, E.D., Gomez, N., Naughten, K.A., Bernales, J., Trusel, L.D., Edwards, T.L., 2019. Global environmental consequences of twenty-first-century ice-sheet melt. Nature 566. doi:10.1038/s41586-019-0889-9.

Goosse, H., Zunz, V., 2014. Decadal trends in the Antarctic sea ice extent ultimately controlled by ice-ocean feedback. Cryosphere 8, 453-470. doi:10.5194/tc-8-453-2014.

Goosse, H., Brovkin, V., Fichefet, T., Haarsma, R., Huybrechts, P., Jongma, J., Mouchet, A., Selten, F., Barriat, P.Y., Campin, J.M., Deleersnijder, E., Driesschaert, E., Goelzer, H., Janssens, I., Loutre, M.F., Morales Maqueda, M.A., Opsteegh, T., Mathieu, P.P., Munhoven, G., Pettersson, E.J., Renssen, H., Roche, D.M., Schaeffer, M., Tartinville, B., Timmermann, A., Weber, S.L., 2010. Description of the Earth system model of intermediate complexity LOVECLIM version 1.2. Geosci. Model Dev. 3, 603-633. doi:10.5194/gmd-3-603-2010.

Goosse, H., Kay, J.E., Armour, K.C., Bodas-Salcedo, A., Chepfer, H., Docquier, D., Jonko, A., Kushner, P.J., Lecomte, O., Massonnet, F., Park, H.S., Pithan, F., Svensson, G., Vancoppenolle, M., 2018. Quantifying climate feedbacks in polar regions. Nat. Commun. 9. doi:10.1038/s41467-018-04173-0. 
Grant, K.M., Rohling, E.J., Ramsey, C.B., Cheng, H., Edwards, R.L., Florindo, F., Heslop, D., Marra, F., Roberts, A.P., Tamisiea, M.E., Williams, F., 2014. Sea-level variability over five glacial cycles. Nat. Commun. 5, 5076. doi:10.1038/ncomms6076.

Greenbaum, J.S., Blankenship, D.D., Young, D.A., Richter, T.G., Roberts, J.L., Aitken, A.R.A., Legresy, B., Schroeder, D.M., Warner, R.C., Van Ommen, T.D., Siegert, M.J., 2015. Ocean access to a cavity beneath Totten glacier in East Antarctica. Nat. Geosci. 8, 294-298. doi:10.1038/ngeo2388.

Grosse, G., Romanovsky, V., Jorgenson, T., Anthony, K.W., Brown, J., Overduin, P.P., 2011. Vulnerability and feedbacks of permafrost to climate change. Eos (Washington. DC) 92, 73-74. doi:10.1029/2011EO090001.

Harrison, S.P., Kutzbach, J.E., Prentice, I.C., Behling, P.J., Sykes, M.T., 1995. The response of northern hemisphere extratropical climate and vegetation to orbitally in duced changes in insolation during the last interglaciation. Quat. Res. 43, 174-184.

Hayes, C.T., Martínez-García, A., Hasenfratz, A.P., Jaccard, S.L., Hodell, D.A., Sigman, D.M., Haug, G.H., Anderson, R.F., 2014. A stagnation event in the deep south at lantic during the last interglacial period. Science 346, 1514-1517. doi:10.1126/ science.1256620.

Hein, A.S., Woodward, J., Marrero, S.M., Dunning, S.A., Steig, E.J., Freeman, S.P.H.T., Stuart, F.M., Winter, K., Westoby, M.J., Sugden, D.E., 2016. Evidence for the stabil ity of the west Antarctic ice sheet divide for 1.4 million years. Nat. Commun. 7, 1-8. doi: $10.1038 /$ ncomms10325.

Helsen, M.M., Van De Berg, W.J., Van De Wal, R.S.W., Van Den Broeke, M.R., Oerlemans, J., 2013. Coupled regional climate-ice-sheet simulation shows limited Greenland ice loss during the Eemian. Clim. Past 9, 1773-1788. doi:10.5194/cp-9-1773-2013.

Hobbs, W.R., Massom, R., Stammerjohn, S., Reid, P., Williams, G., Meier, W., 2016. A re view of recent changes in Southern Ocean sea ice, their drivers and forcings. Global Planet. Change 143, 228-250. doi:10.1016/j.gloplacha.2016.06.008.

Hodell, D.A., Venz, K.A., Charles, C.D., Ninnemann, U.S., 2003. Pleistocene vertical carbon isotope and carbonate gradients in the South Atlantic sector of the Southern Ocean. Geochem. Geophys. Geosyst. 4, 1-19. doi:10.1029/2002GC000367.

Hoffman, J.S., Parnell, A.C., He, F., 2017. Regional and global sea-surface temperatures during the last interglaciation. Science 279, 276-279.

Holland, M.M., Landrum, L., Kostov, Y., Marshall, J., 2017. Sensitivity of Antarctic sea ice to the Southern Annular Mode in coupled climate models. Clim. Dynam. 49, 1813-1831. doi:10.1007/s00382-016-3424-9.

Hollesen, J., Matthiesen, H., Møller, A.B., Elberling, B., 2015. Permafrost thawing in organic Arctic soils accelerated by ground heat production. Nat. Clim. Change 5 , 574-578. doi:10.1038/nclimate2590.

Holloway, M.D., Sime, L.C., Singarayer, J.S., Tindall, J.C., Bunch, P., Valdes, P.J., 2016 Antarctic last interglacial isotope peak in response to sea ice retreat not ice-sheet collapse. Nat. Commun. 7, 12293. doi:10.1038/ncomms12293.

Hosking, J.S., Orr, A., Marshall, G.J., Turner, J., Phillips, T., 2013. The influence of the amundsen-bellingshausen seas low on the climate of West Antarctica and its represen tation in coupled climate model simulations. J. Clim. 26, 6633-6648. doi:10.1175/ JCLI-D-12-00813.1.

IPCC AR5, 2013. Climate Change 2013: the Physical Science Basis. Contribution of Working Group I to the Fifth Assessment Report of the Intergovernmental Panel on Climate Change [. Cambridge University Press, Cambridge, United Kingdom and New York NY, USA.

Irvali, N., Ninnemann, U.S., Galaasen, E.V., Rosenthal, Y., Kroon, D., Oppo, D.W., Kleiven, H.F., Darling, K.F., Kissel, C., 2012. Rapid switches in subpolar North Atlantic hydrography and climate during the Last Interglacial (MIS 5e). Paleoceanography 27, 1-16. doi:10.1029/2011PA002244.

Jones, J.M., Gille, S.T., Goosse, H., Abram, N.J., Canziani, P.O., Charman, D.J., Clem, K.R., Crosta, X., de Lavergne, C., Eisenman, I., England, M.H., Fogt, R.L., Frankcombe, L.M., Marshall, G.J., Masson-Delmotte, V., Morrison, A.K., Orsi, A.J., Raphael, M.N., Renwick, J.A., Schneider, D.P., Simpkins, G.R., Steig, E.J., Stenni, B., Swingedouw, D., Vance, T.R., 2016. Assessing recent trends in high-latitude Southern Hemisphere surface climate. Nat. Clim. Change 6, 917-926. doi:10.1038/nclimate3103.

Joughin, I., Smith, B.E., Medley, B., 2014. Marine ice sheet collapse potentially underway for the Thwaites glacier basin, west Antarctica. Science 344, 735-738. doi:10.1126/ science. 1249055 .

Kageyama, M., Braconnot, P., Harrison, S.P., Haywood, A.M., Jungclaus, J.H., Otto-Bliesner, B.L., Abe-Ouchi, A., Albani, S., Bartlein, P.J., Brierley, C., Crucifix, M., Dolan, A. Fernandez-Donado, L.L., Fischer, H., Hopcroft, P.O., Ivanovic, R.F., Lambert, F., Lunt, D.J., Mahowald, N.M., Richard Peltier, W., Phipps, S.J., Roche, D.M., Schmidt, G.A., Tarasov, L., Valdes, P.J., Zhang, Q., Zhou, T., 2018. The PMIP4 contribution to CMIP6 - Part 1: overview and over-arching analysis plan. Geosci. Model Dev. 11, 1033-1057. doi:10.5194/gmd-11-1033-2018.

Kienast, F., Tarasov, P., Schirrmeister, L., Grosse, G., Andreev, A.A., 2008. Continental climate in the East Siberian Arctic during the last interglacial: implications from palaeobotanical records. Global Planet. Change 60, 535-562. doi:10.1016/ j.gloplacha.2007.07.004

Kingslake, J., Scherer, R.P., Albrecht, T., Coenen, J., Powell, R.D., Reese, R., Stansell, N.D., Tulaczyk, S., Wearing, M.G., Whitehouse, P.L., 2018. Extensive retreat and re-advance of the west Antarctic ice sheet during the Holocene. Nature 558, 430-434. doi:10.1038/s41586-018-0208-x.

Kopp, R.E., Simons, F.J., Maloof, A.C., Oppenheimer, M., 2009. Global and local sea level during the Last Interglacial: a probabilistic assessment. Nature 462, 863-867. doi:10.1038/nature08686.

Kwok, R., 2007. Near zero replenishment of the Arctic multiyear sea ice cover at the end of 2005 summer. Geophys. Res. Lett. 34, 1-6. doi:10.1029/2006GL028737.

Kwok, R., 2018. Arctic sea ice thickness, volume, and multiyear ice coverage: losse and coupled variability (1958-2018). Environ. Res. Lett. 13, 105005. doi:10.1088/ 1748-9326/aae3ec.

Lauriol, B., Ford, D.C., Cinq-Mars, J., Morris, W.A., 1997. The chronology of speleothem deposition in northern Yukon and its relationships to permafrost. Can. J. Earth Sci. 34, 902-911. doi:10.1139/e17-075.
Lee, H., Schuur, E.A.G., Inglett, K.S., Lavoie, M., Chanton, J.P., 2012. The rate of permafrost carbon release under aerobic and anaerobic conditions and its potential effects on climate. Global Change Biol. 18, 515-527. doi:10.1111/ j.1365-2486.2011.02519.x.

Lenton, T.M., Ciscar, J.-C., 2013. Integrating tipping points into climate impact assessments. Clim. Change 117, 585-597. doi:10.1007/s10584-012-0572-8.

Lenton, T.M., Williams, H.T.P., 2013. On the origin of planetary-scale tipping points. Trends Ecol. Evol. 28, 380-382. doi:10.1016/j.tree.2013.06.001.

Lenton, T.M., Held, H., Kriegler, E., Hall, J.W., Lucht, W., Rahmstorf, S., Schellnhuber, H.J., 2008. Tipping elements in the Earth's climate system. Proc. Natl. Acad. Sci. U.S.A. 105, 1786-1793. doi:10.1073/pnas.0705414105.

Levermann, A., Feldmann, J., 2019. Scaling of instability time-scales of Antarctic outlet glaciers based on one-dimensional similitude analysis. Cryosphere 13, 1621-1633. doi:10.5194/tc-2018-252.

Levermann, A., Bamber, J.L., Drijfhout, S., Ganopolski, A., Haeberli, W., Harris, N.R.P., Huss, M., Krüger, K., Lenton, T.M., Lindsay, R.W., Notz, D., Wadhams, P., Weber, S., 2012. Potential climatic transitions with profound impact on Europe. Clim. Change 110, 845-878. doi:10.1007/s10584-011-0126-5.

LIGA members, Anderson, P., Borisova, O., de Beaulieu, J.L., de Vernal, A., Eiriksson, J., Funder, S., Gibbard, P., Hamilton, T., Harrison, S.P., Houmark-Nielsen, M., Huntley, B., Knudsen, K.L., Larsen, E., Maher, L.J., Matthews, J.V., Miller, G., Raukas, A., Reeh N., Robertsson, A.M., Rutter, N., Schweger, C.E., Sejrup, H.P., Sher, A., Telka, A., Turner, C., Velichko, A., Ward, B., 1991. Report of 1st discussion group: the last interglacial in high latitudes of the Northern Hemisphere: terrestrial and marine evidence. Quat. Int. 10-12, 9-28. doi:10.1016/1040-6182(91)90038-P.

Liu, Y., Moore, J.C., Cheng, X., Gladstone, R.M., Bassis, J.N., Liu, H., Wen, J., Hui, F., 2015. Ocean-driven thinning enhances iceberg calving and retreat of Antarctic ice shelves. Proc. Natl. Acad. Sci. 112, 3263-3268. doi:10.1073/pnas.1415137112.

Lloyd, A.H., Rupp, T.S., Fastie, C.L., Starfield, A.M., 2002. Patterns and dynamics of treeline advance on the Seward Peninsula, Alaska. J. Geophys. Res. 108, 8161. doi:10.1029/2001JD000852.

Loulergue, L., Schilt, A., Spahni, R., Masson-Delmotte, V., Blunier, T., Lemieux, B., Barnola, J.-M., Raynaud, D., Stocker, T.F., Chappellaz, J., 2008. Orbital and millennial-scale features of atmospheric CH4 over the past 800,000 years. Nature 453, 383-386. doi:10.1038/nature06950.

Løwemark, L., Chao, W.S., Gyllencreutz, R., Hanebuth, T.J.J., Chiu, P.Y., Yang, T.N., Su, C.C., Chuang, C.K., Leon Dominguez, D.C., Jakobsson, M., 2016. Variations in glacial and interglacial marine conditions over the last two glacial cycles off northern Greenland. Quat. Sci. Rev. 147, 164-177. doi:10.1016/j.quascirev.2015.10.035.

Lozhkin, A.V., Anderson, P.M., 1995. The last interglaciation in northeast Sibera. Quat. Res. doi:10.1006/qres.1995.1016.

Lunt, D.J., Abe-Ouchi, A., Bakker, P., Berger, A., Braconnot, P., Charbit, S., Fischer, N., Herold, N., Jungclaus, J.H., Khon, V.C., Krebs-Kanzow, U., Langebroek, P.M., Lohmann, G., Nisancioglu, K.H., Otto-Bliesner, B.L., Park, W., Pfeiffer, M., Phipps, S.J., Prange, M., Rachmayani, R., Renssen, H., Rosenbloom, N., Schneider, B., Stone, E.J., Takahashi, K., Wei, W., Yin, Q., Zhang, Z.S., 2013. A multi-model assessment of last interglacial temperatures. Clim. Past 9, 699-717. doi:10.5194/cp-9-699-2013.

Lüthi, D., Le Floch, M., Bereiter, B., Blunier, T., Barnola, J.-M., Siegenthaler, U., Raynaud, D., Jouzel, J., Fischer, H., Kawamura, K., Stocker, T.F., 2008. High-resolution carbon dioxide concentration record $650,000-800,000$ years before present. Nature 453, 379-382. doi:10.1038/nature06949.

Marino, G., Rohling, E.J., Rodríguez-Sanz, L., Grant, K.M., Heslop, D., Roberts, A.P., Stanford, J.D., Yu, J., 2015. Bipolar seesaw control on last interglacial sea level. Nature 522, 197-201. doi:10.1038/nature14499.

Marshall, G.J., 2003. Trends in the southern annular mode from observations and reanalyses. J. Clim. 16, 4134-4143. doi:10.1175/ 1520-0442(2003)016<4134:TITSAM > 2.0.CO;2.

Marshall, M., 2013. Arctic thaw may be first in cascade of tipping points. New Sci..

Massom, R.A., Scambos, T.A., Bennetts, L.G., Reid, P., Squire, V.A., Stammerjohn, S.E., 2018. Antarctic ice shelf disintegration triggered by sea ice loss and ocean swell. Nature 558, 383-389. doi:10.1038/s41586-018-0212-1.

Masson-Delmotte, V., Stenni, B., Pol, K., Braconnot, P., Cattani, O., Falourd, S., Kageyama, M., Jouzel, J., Landais, A., Minster, B., Barnola, J.M., Chappellaz, J., Krinner, G., Johnsen, S., Röthlisberger, R., Hansen, J., Mikolajewicz, U., Otto-Bliesner, B., 2010. EPICA Dome C record of glacial and interglacial intensities. Quat. Sci. Rev. 29, 113-128. doi:10.1016/j.quascirev.2009.09.030.

Masson-Delmotte, V., Schulz, M., Abe-Ouchi, A., Beer, J., Ganopolski, A., Rouco, J.F.G., Jansen, E., Lambeck, K., Luterbacher, J., Naish, T., Osborn, T., Otto-Bliesner, B., Quinn, T., Ramesh, R., Rojas, M., Shao, X., Timmermann, A., 2013. Information from paleoclimate archives. In: Stocker, T.F., Qin, D., Plattner, G.-K., Tignor, M., Allen, S.K. Boschung, J., Nauels, A., Xia, Y., Bex, V., Midgley, P.M. (Eds.), Climate Change 2013 the Physical Science Basis: Working Group I Contribution to the Fifth Assessment Report of the Intergovernmental Panel on Climate Change. Cambridge University Press, Cambridge, United Kingdom and New York, NY, USA, pp. 383-464. doi:10.1017/ CBO9781107415324.013.

Matthiessen, J., Knies, J., 2001. Dinoflagellate cyst evidence for warm interglacial conditions at the Northern Barents Sea margin during marine oxygen isotope stage 5. J. Quat. Sci. 16, 727-737. doi:10.1002/jqs.656.

Matthiessen, J., Knies, J., Nowaczyk, N.R., Stein, R., 2001. Late Quaternary dinoflagellate cyst stratigraphy at the Eurasian continental margin, Arctic Ocean: indications for Atlantic water inflow in the past 150,000 years. Global Planet. Change 31, 65-86. doi:10.1016/S0921-8181(01)00113-8.

McKay, N.P., Overpeck, J.T., Otto-Bliesner, B.L., 2011. The role of ocean thermal expansion in Last Interglacial sea level rise. Geophys. Res. Lett. 38, 4-9. doi:10.1029/ 2011GL048280.

Melia, N., Haines, K., Hawkins, E., 2016. Sea ice decline and 21st century trans-Arctic shipping routes. Geophys. Res. Lett. 43, 9720-9728, doi:10.1002/2016GL069315.

Menezes, V.V., Macdonald, A.M., Schatzman, C., 2017. Accelerated freshening of Antarctic bottom water over the last decade in the southern Indian ocean. Sci. Adv. 3, 1-10. doi:10.1126/sciadv.1601426. 
Mengel, M., Levermann, A., 2014. Ice plug prevents irreversible discharge from East Antarctica. Nat. Clim. Change 4, 451-455. doi:10.1038/nclimate2226.

Menviel, L., Timmermann, A., Timm, O.E., Mouchet, A., 2010. Climate and biogeochemical response to a rapid melting of the West Antarctic Ice sheet during interglacials and implications for future climate. Paleoceanography 25, 1-12. doi:10.1029/ 2009PA001892.

Menviel, L., Spence, P., Yu, J., Chamberlain, M.A., Matear, R.J., Meissner, K.J., England, M.H., 2018. Southern Hemisphere westerlies as a driver of the early deglacial atmospheric CO2rise. Nat. Commun. 9, 1-12. doi:10.1038/s41467-018-04876-4.

Mercer, J., 1969. The Allerød oscillation: a European climatic anomaly? Arct. Alp. Res. 1, 227-234.

Mercer, J.H., 1978. West Antarctic ice sheet and CO2 greenhouse effect: a threat of disaster. Nature 271, 321-325.

Mitchard, E.T.A., 2018. The tropical forest carbon cycle and climate change. Nature 559, 527. 2018 5597715. doi:10.1038/s41586-018-0300-2.

Muhs, D.R., Ager, T.A., Begét, J.E., 2001. Vegetation and paleoclimate of the last interglacial period, central Alaska. Quat. Sci. Rev. 20, 41-61. doi:10.1016/ S0277-3791(00)00132-3.

Naish, T., Zwartz, D., 2012. Palaeoclimate: looking back to the future. Nat. Clim. Change 2, 317-318. doi:10.1038/nclimate1504.

NEEM community members, 2013. Eemian interglacial reconstructed from a Greenland folded ice core. Nature 493, 489-494. doi:10.1038/nature11789.

Neumann, B., Vafeidis, A.T., Zimmermann, J., Nicholls, R.J., 2015. Future coastal population growth and exposure to sea-level rise and coastal flooding - a global assessment. PloS One 10. doi:10.1371/journal.pone.0118571.

Neumann, R.B., Moorberg, C.J., Lundquist, J.D., Turner, J.C., Waldrop, M.P., McFarland, J.W., Euskirchen, E.S., Edgar, C.W., Turetsky, M.R., 2019. Warming effects of spring rainfall increase methane emissions from thawing permafrost. Geophys. Res. Lett. doi:10.1029/2018GL081274.

NGRIP members, Andersen, K.K., Azuma, N., Barnola, J.-M., Bigler, M., Biscaye, P., Caillon, N., Chappellaz, J., Clausen, H.B., Dahl-Jensen, D., Fischer, H., Flückiger, J., Fritzsche, D., Fujii, Y., Goto-Azuma, K., Grønvold, K., Gundestrup, N.S., Hansson, M., Huber, C., Hvidberg, C.S., Johnsen, S.J., Jonsell, U., Jouzel, J., Kipfstuhl, S., Landais, A., Leuenberger, M., Lorrain, R., Masson-Delmotte, V., Miller, H., Motoyama, H., Narita, H., Popp, T., Rasmussen, S.O., Raynaud, D., Rothlisberger, R., Ruth, U., Samyn, D., Schwander, J., Shoji, H., Siggard-Andersen, M.-L., Steffensen, J.P., Stocker, T., Sveinbjörnsdóttir, A.E., Svensson, A., Takata, M., Tison, J.-L., Thorsteinsson, T., Watanabe, O., Wilhelms, F., White, J.W.C., 2004. High-resolution record of Northern Hemisphere climate extending into the last interglacial period. Nature 431, 147-151. doi:10.1038/nature02805.

Nicholl, J.A.L., Hodell, D.A., Naafs, B.D.A., Hillaire-Marcel, C., Channell, J.E.T., Romero, O.E., 2012. A Laurentide outburst flooding event during the last interglacial period. Nat. Geosci. 5, 901-904. doi:10.1038/ngeo1622.

Nikolova, I., Yin, Q., Berger, A., Singh, U.K., Karami, M.P., 2013. The last interglacial (Eemian) climate simulated by LOVECLIM and CCSM3. Clim. Past 9, 1789-1806. doi:10.5194/cp-9-1789-2013.

Nørgaard-Pedersen, N., Mikkelsen, N., Lassen, S.J., Kristoffersen, Y., Sheldon, E., 2007. Reduced sea ice concentrations in the Arctic Ocean during the last interglacial period revealed by sediment cores off northern Greenland. Paleoceanography 22, 1-15. doi:10.1029/2006PA001283.

Notz, D., 2009. The future of ice sheets and sea ice: between reversible retreat and unstoppable loss. Proc. Natl. Acad Sci. U.S.A. 106. 20590-5. doi:10.1073/pnas.0902356106.

Orlando, L., Ginolhac, A., Zhang, G., Froese, D., Albrechtsen, A., Stiller, M., Schubert, M., Cappellini, E., Petersen, B., Moltke, I., Johnson, P.L.F., Fumagalli, M., Vilstrup, J.T., Raghavan, M., Korneliussen, T., Malaspinas, A.-S., Vogt, J., Szklarczyk, D., Kelstrup, C.D., Vinther, J., Dolocan, A., Stenderup, J., Velazquez, A.M.V., Cahill, J., Rasmussen, M., Wang, X., Min, J., Zazula, G.D., Seguin-Orlando, A., Mortensen, C., Magnussen, K., Thompson, J.F., Weinstock, J., Gregersen, K., Røed, K.H., Eisenmann, V., Rubin, C.J., Miller, D.C., Antczak, D.F., Bertelsen, M.F., Brunak, S., Al-Rasheid, K.A.S., Ryder, O., Andersson, L., Mundy, J., Krogh, A., Gilbert, M.T.P., Kjær, K., Sicheritz-Ponten, T., Jensen, L.J., Olsen, J.V., Hofreiter, M., Nielsen, R., Shapiro, B., Wang, J., Willerslev, E., 2013. Recalibrating Equus evolution using the genome sequence of an early Middle Pleistocene horse. Nature 499, 74-78. doi:10.1038/nature12323.

Otto-Bliesner, B.L., Marshall, S.J., Overpeck, J.T., Miller, G.H., 2006. Simulating arctic climate warmth and icefield retreat in the last interglaciation. Science 1751-1754.

Otto-Bliesner, B.L., Rosenbloom, N., Stone, E.J., Mckay, N.P., Lunt, D.J., Brady, E.C., Overpeck, J.T., 2013. How warm was the last interglacial? New model-data comparisons. Philos. Trans. R. Soc. A Math. Phys. Eng. Sci. 371. doi:10.1098/rsta.2013.0097.

Otto-Bliesner, B.L., Brady, E.C., Zhao, A., Brierley, C., Axford, Y., Capron, E., Govin, A., Hoffman, J., Isaacs, E., Kageyama, M., Tzedakis, P.C., Williams, C., Wolff, E., Abe-Ouchi, A., Braconnot, P., Ramos Buarque, S., Cao, J., de Vernal, A., Vittoria Guarino, M., Guo, C., Sicard, M., Sime, L., Tomas, R., Volodin, E., Yeung, N., Zhang, Z., Zheng, W., 2020. Large-scale features of Last Interglacial climate: results from evaluating the lig127k simulations for CMIP6-PMIP4. David Salas Y Melia 17. doi:10.5194/ cp-2019-174.

Overpeck, J.T., Otto-bliesner, B.L., Miller, G.H., Muhs, D.R., Alley, R.B., Kiehl, J.T., 2006. Paleoclimatic evidence for future rapid sea-level rise. Science 2934, 1747-1750. doi:10.1126/science.1115159.

Pahnke, K., Zahn, R., 2005. Southern hemisphere water mass conversion linked with North Atlantic climate variability. Science $307,1741-1747$.

Payne, A.J., Vieli, A., Shepherd, A.P., Wingham, D.J., Rignot, E., 2004. Recent dramatic thinning of largest West Antarctic ice stream triggered by oceans. Geophys. Res. Lett. 31, 1-4. doi:10.1029/2004GL021284.

Peck, L.S., Barnes, D.K.A., Cook, A.J., Fleming, A.H., Clarke, A., 2010. Negative feedback in the cold: ice retreat produces new carbon sinks in Antarctica. Global Change Biol. 16, 2614-2623. doi:10.1111/j.1365-2486.2009.02071.x.
Peng, G., Meier, W.N., 2018. Temporal and regional variability of Arctic sea-ice coverage from satellite data. Ann. Glaciol. 59, 191-200. doi:10.1017/aog.2017.32.

Pollard, D., DeConto, R.M., Alley, R.B., 2015. Potential Antarctic Ice Sheet retreat driven by hydrofracturing and ice cliff failure. Earth Planet Sci. Lett. 412, 112-121. doi:10.1016/j.epsl.2014.12.035.

Polyak, L., Alley, R.B., Andrews, J.T., Brigham-Grette, J., Cronin, T.M., Darby, D.A., Dyke, A.S., Fitzpatrick, J.J., Funder, S., Holland, M., Jennings, A.E., Miller, G.H. O'Regan, M., Savelle, J., Serreze, M., St John, K., White, J.W.C., Wolff, E., 2010. History of sea ice in the Arctic. Quat. Sci. Rev. 29, 1757-1778. doi:10.1016/ j.quascirev.2010.02.010.

Post, E., Bhatt, U.S., Bitz, C.M., Brodie, J.F., Fulton, T.L., Hebblewhite, M., Kerby, J., Kutz, S.J., Stirling, I., Walker, D.A., 2013. Ecological consequences of sea-ice decline. Science $341,519-525$.

Preece, S.J., Pearce, N.J.G., Westgate, J.A., Froese, D.G., Jensen, B.J.L., Perkins, W.T., 2011. Old Crow tephra across eastern Beringia: a single cataclysmic eruption at the close of Marine Isotope Stage 6. Quat. Sci. Rev. 30, 2069-2090. doi:10.1016/ j.quascirev.2010.04.020.

Purich, A., Cai, W., England, M.H., Cowan, T., 2016. Evidence for link between modelled trends in Antarctic sea ice and underestimated westerly wind changes. Nat. Commun. 7, 10409. doi:10.1038/ncomms10409.

Pycroft, J., Abrell, J., Ciscar, J.C., 2016. The global impacts of extreme sea-level rise: a comprehensive economic assessment. Environ. Resour. Econ. 64, 225-253. doi:10.1007/s10640-014-9866-9.

Radić, V., Hock, R., 2011. Regionally differentiated contribution of mountain glaciers and ice caps to future sea-level rise. Nat. Geosci. 4, 91-94. doi:10.1038/ngeo1052.

Rahmstorf, S., Box, J.E., Feulner, G., Mann, M.E., Robinson, A., Rutherford, S., Scha, E.J., 2015. Exceptional twentieth-century slowdown in Atlantic Ocean overturning circulation. Nat. Clim. Change 5, 475-480. doi:10.1038/NCLIMATE2554.

Raynaud, D., Chappellaz, J., Ritz, C., Martinerie, P., 1997. Air content along the Greenland Ice Core Project core: a record of surface climatic parameters and elevation in centra Greenland. J. Geophys. Res. Ocean. 102, 26607-26613. doi:10.1029/97JC01908.

Reyer, C.P.O., Brouwers, N., Rammig, A., Brook, B.W., Epila, J., Grant, R.F., Holmgren, M., Langerwisch, F., Leuzinger, S., Medlyn, B., Pfeifer, M., Verbeeck, H., Villela, D.M., 2015. Forest resilience and tipping points at different spatio-temporal scales: approaches and challenges. J. Ecol. 103, 5-15. doi:10.1111/1365-2745.12337.

Reyes, A.V., Froese, D.G., Jensen, B.J.L., 2010. Permafrost response to last interglacial warming: field evidence from non-glaciated Yukon and Alaska. Quat. Sci. Rev. 29, 3256-3274. doi:10.1016/j.quascirev.2010.07.013.

Rignot, E., Velicogna, I., Van Den Broeke, M.R., Monaghan, A., Lenaerts, J., 2011. Acceleration of the contribution of the Greenland and Antarctic ice sheets to sea level rise. Geophys. Res. Lett. 38, 1-5. doi:10.1029/2011GL046583.

Rignot, E., Jacobs, S., Mouginot, J., Scheuchl, B., 2013. Ice shelf melting around Antarctica. Science 1, 1-15. doi:10.1126/science.1235798.

Rintoul, S.R., 2018. The global influence of localized dynamics in the Southern Ocean. Nature 558, 209-218. doi:10.1038/s41586-018-0182-3.

Ritz, C., Edwards, T.L., Durand, G., Payne, A.J., Peyaud, V., Hindmarsh, R.C.A., 2015. Potential sea-level rise from Antarctic ice-sheet instability constrained by observations. Nature doi:10.1038/nature16147.

Rohling, E.J., Hibbert, F.D., Williams, F.H., Grant, K.M., Marino, G., Foster, G.L., Hennekam, R., de Lange, G.J., Roberts, A.P., Yu, J., Webster, J.M., Yokoyama, Y., 2017 Differences between the last two glacial maxima and implications for ice-sheet, 8180, and sea-level reconstructions. Quat. Sci. Rev. 176, 1-28. doi:10.1016/ j.quascirev.2017.09.009.

Saarnisto, M., Lunkka, J.P., 2004. Climate variability during the last interglacial-glacia cycle in NW Eurasia. In: Battarbee, R.W., Gasse, F., Stickley, C.E. (Eds.), Past Climate Variability through Europe and Africa. Springer Netherlands, Dordrecht, pp. 443-464. doi:10.1007/978-1-4020-2121-3_21.

Saarnisto, M., Eriksson, B., Hirvas, H., 1999. Tepsankumpu revisited - pollen evidence of stable Eemian climates in Finnish Lapland. Boreas 1999, 12-22.

Schaefer, J.M., Denton, G.H., Kaplan, M., Putnam, A., Finkel, R.C., Barrell, D.J. a, Andersen, B.G., Schwartz, R., Mackintosh, A., Chinn, T., Schlüchter, C., 2009. High-frequency Holocene glacier fluctuations in New Zealand differ from the northern signature. Science 324, 622-625. doi:10.1126/science.1169312.

Schaefer, K., Lantuit, H., Romanovsky, V.E., Schuur, E.A.G., Witt, R., 2014. The impact of the permafrost carbon feedback on global climate. Environ. Res. Lett. 9. doi:10.1088/ 1748-9326/9/8/085003.

Schaeffer, M., Hare, W., Rahmstorf, S., Vermeer, M., 2012. Long-term sea-level rise implied by $1.5^{\circ} \mathrm{C}$ and $2{ }^{\circ} \mathrm{C}$ warming levels. Nat. Clim. Change 2, 867-870. doi:10.1038/ nclimate1584.

Scheffer, M., Carpenter, S., Foley, J.A., Folke, C., Walker, B., 2001. Catastrophic shifts in ecosystems. Nature 413, 591-596. doi:10.1038/35098000.

Scheffer, M., Bascompte, J., Brock, W.A., Brovkin, V., Carpenter, S.R., Dakos, V., Held, H., van Nes, E.H., Rietkerk, M., Sugihara, G., 2009. Early-warning signals for critical transitions. Nature 461, 53-59. doi:10.1038/nature08227.

Schellnhuber, H.J., Rahmstorf, S., Winkelmann, R., 2016. Why the right climate target was agreed in Paris. Nat. Clim. Change 6, 649-653.

Schoof, C., 2007. Ice sheet grounding line dynamics: steady states, stability, and hysteresis. J. Geophys. Res. Earth Surf. 112, 1-19. doi:10.1029/2006JF000664.

Schröder, D., Feltham, D.L., Flocco, D., Tsamados, M., 2014. September Arctic sea-ice minimum predicted by spring melt-pond fraction. Nat. Clim. Change 4, 353-357. doi:10.1038/nclimate2203.

Schurgers, G., Mikolajewicz, U., Gröger, M., Maier-Reimer, E., Vizcaïno, M., Winguth, A., 2007. The effect of land surface changes on Eemian climate. Clim. Dynam. 29, 357-373. doi:10.1007/s00382-007-0237-x.

Screen, J.A., 2013. Influence of Arctic sea ice on European summer precipitation. Environ Res. Lett. 8, 044015. doi:10.1088/1748-9326/8/4/044015.

Screen, J.A., Simmonds, I., 2010. The central role of diminishing sea ice in recent Arctic temperature amplification. Nature 464, 1334-1337. doi:10.1038/nature09051. 
Screen, J.A., Simmonds, I., 2013. Exploring links between Arctic amplification and mid-latitude weather. Geophys. Res. Lett. 40, 959-964. doi:10.1002/grl.50174.

Screen, J.A., Williamson, D., 2017. Ice-free arctic at $1.5^{\circ}$ c? Nat. Clim. Change 7, 230-231. doi:10.1038/nclimate3248.

Scussolini, P., Bakker, P., Guo, C., Stepanek, C., Zhang, Q., Braconnot, P., Cao, J., Guarino, M.V., Coumou, D., Prange, M., Ward, P.J., Renssen, H., Kageyama, M., Otto-Bliesner, B., Aerts, J.C.J.H., 2019. Agreement between reconstructed and modeled boreal precipitation of the last interglacial. Sci. Adv. 5, 1-12. doi:10.1126/sciadv.aax7047.

Serreze, M.C., Barry, R.G., 2011. Processes and impacts of Arctic amplification: a research synthesis. Global Planet. Change 77, 85-96. doi:10.1016/j.gloplacha.2011.03.004.

Sher, A.V., 1991. Problems of the last interglacial in arctic Siberia. Quat. Int. 10-12, 215-222. doi:10.1016/1040-6182(91)90053-Q.

Silvano, A., Rintoul, S.R., Peña-Molino, B., Hobbs, W.R., van Wijk, E., Aoki, S., Tamura, T., Williams, G.D., 2018. Freshening by glacial meltwater enhances melting of ice shelves and reduces formation of Antarctic Bottom Water. Sci. Adv. 4, eaap9467. doi:10.1126/sciadv.aap9467.

Spielhagen, R.F., Baumann, K.H., Erlenkeuser, H., Nowaczyk, N.R., Nørgaard-Pedersen, N. Vogt, C., Weiel, D., 2004. Arctic Ocean deep-sea record of northern Eurasian ice sheet history. Quat. Sci. Rev. 23, 1455-1483. doi:10.1016/j.quascirev.2003.12.015.

Steffen, W., Crutzen, P.J., McNeill, J., 2007. The Anthropocene: are humans now overwhelming the great forces of nature. Ambio 36, 614. doi:10.1579/ 0044-7447(2007)36.

Steffen, W., Richardson, K., Rockström, J., Cornell, S.E., Fetzer, I., Bennett, E.M., Biggs, R., Carpente, S.R., Vries, W. de, Wit, C.A. de, Folke, C., Gerten, D., Heinke, J., Mace, G.M., Persson, L.M., Ramanathan, V., Reyers, B., Sörlin, S., 2015. Planetary boundaries: guiding human development on a changing planet. Science 347, 1259855 doi:10.1126/science.aaa9629.

Steffen, W., Rockström, J., Richardson, K., Lenton, T.M., Folke, C., Liverman, D., Summerhayes, C.P., Barnosky, A.D., Cornell, S.E., Crucifix, M., Donges, J.F., Fetzer, I., Lade, S.J., Scheffer, M., Winkelmann, R., Schellnhuber, H.J., 2018. Trajectories of the Earth system in the Anthropocene. Proc. Natl. Acad. Sci. U.S.A. 1-8. doi:10.1073/ PNAS.1810141115.

Steig, E.J., Huybers, K., 2015. Influence of collapse of the West Antarctic Ice Sheet on Antarctic surface climate and ice core records. Geophys. Res. Lett. 42, 4862-4868. Abstract. doi:10.1002/2015GL063861.

Stocker, T.F., Johnsen, S.J., 2003. A minimum thermodynamic model for the bipolar seesaw. Paleoceanography 18, 1087-1095. doi:10.1029/2003PA000920.

Stone, E.J., Lunt, D.J., Annan, J.D., Hargreaves, J.C., 2013. Quantification of the Greenland ice sheet contribution to Last Interglacial sea level rise. Clim. Past 9, 621-639. doi:10.5194/cp-9-621-2013.

Stone, E.J., Capron, E., Lunt, D.J., Payne, A.J., Singarayer, J.S., Valdes, P.J., Wolff, E.W 2016. Impact of meltwater on high-latitude early Last Interglacial climate. Clim. Past 12, 1919-1932. doi:10.5194/cp-12-1919-2016.

Sutter, J., Gierz, P., Grosfeld, K., Thoma, M., Lohmann, G., 2016. ocean temperature thresholds for last interglacial West Antarctic ice sheet collapse. Geophys. Res. Lett. 43, 2675-2682. doi:10.1002/2016GL067818.

Suwa, M., von Fischer, J.C., Bender, M.L., Landais, A., Brook, E.J., 2006. Chronology reconstruction for the disturbed bottom section of the GISP2 and the GRIP ice cores: implications for Termination II in Greenland. J. Geophys. Res. Atmos. 111, 1-12. doi:10.1029/2005JD006032.

Svendsen, J.I., Alexanderson, H., Astakhov, V.I., Demidov, I., Dowdeswell, J.A., Funder, S., Gataullin, V., Henriksen, M., Hjort, C., Houmark-Nielsen, M., Hubberten, H.W., Ingólfsson, Ó., Jakobsson, M., Kjær, K.H., Larsen, E., Lokrantz, H., Lunkka, J.P., Lyså, A., Mangerud, J., Matiouchkov, A., Murray, A., Möller, P., Niessen, F., Nikolskaya, O., Polyak, L., Saarnisto, M., Siegert, C., Siegert, M.J., Spielhagen, R.F., Stein, R., 2004 Late Quaternary ice sheet history of northern Eurasia. Quat. Sci. Rev. 23, 1229-1271. doi:10.1016/j.quascirev.2003.12.008.

Swann, A.L., Fung, I.Y., Levis, S., Bonan, G.B., Doney, S.C., 2010. Changes in Arctic vegetation amplify high-latitude warming through the greenhouse effect. Proc. Natl. Acad. Sci. 107, 1295-1300. doi:10.1073/pnas.0913846107.

Tarasov, P., Granoszewski, W., Bezrukova, E., Brewer, S., Nita, M., Abzaeva, A., Oberhänsli, H., 2005. Quantitative reconstruction of the last interglacial vegetation and climate based on the pollen record from Lake Baikal, Russia. Clim. Dynam. 25, 625-637. doi:10.1007/s00382-005-0045-0.

Thomas, Z.A., 2016. Using natural archives to detect climate and environmental tipping points in the Earth System. Quat. Sci. Rev. 152, 60-71. doi:10.1016/ j.quascirev.2016.09.026

Thomas, Z.A., Kwasniok, F., Boulton, C.A., Cox, P.M., Jones, R.T., Lenton, T.M., Turney, C.S.M., 2015. Early warnings and missed alarms for abrupt monsoon transitions. Clim. Past 11, 1313-1341. doi:10.5194/cpd-11-1313-2015.

Thomas, Z.A., Jones, R.T., Fogwill, C.J., Hatton, J., Williams, A., Hogg, A.G., Mooney, S.D., Jones, P.D., Lister, D., Mayewski, P.A., Turney, C.S.M., 2018. Evidence for increased expression of the Amundsen Sea low over the south atlantic during the late Holocene. Clim. Past 14, 1727-1738. doi:10.5194/cp-14-1727-2018.

Thomas, Z.A., Turney, C., Allan, R., Colwell, S., Kelly, G., Lister, D., Jones, P., Beswick, M., Alexander, L., Lippmann, T., Herold, N., Jones, R., 2018. A new daily observational record from Grytviken, South Georgia: exploring 20th century extremes in the South Atlantic. J. Clim. 31, 1743-1755. doi:10.1175/JCLI-D-17-0353.1.

Thornalley, D.J.R., Delia, W., Ortega, P., Robson, J.I., Brierley, C.M., Davis, R., Hall, I.R., Moffa-sanchez, P., Rose, N.L., Spooner, P.T., Yashayaev, I., Keigwin, L.D., 2018 Anomalously weak Labrador Sea convection and Atlantic overturning during the past 150 years. Nature 556, 227-230. doi:10.1038/s41586-018-0007-4.

Turner, J., Colwell, S.R., Marshall, G.J., Lachlan-Cope, T.A., Carleton, A.M., Jones, P.D., Lagun, V., Reid, P.A., Iagovkina, S., 2005. Antarctic climate change during the last 50 years. Int. J. Climatol. 25, 279-294. doi:10.1002/joc.1130.

Turner, J., Hosking, J.S., Bracegirdle, T.J., Marshall, G.J., Phillips, T., Tj, B., Gj, M. Phillips, T., Ice, S., Trans, P., Soc, R.A., Turner, J., 2015. Recent changes in Antarctic sea ice. Philos. Trans. R. Soc. A 373, 20140163. doi:10.1098/rsta.2014.0163.
Turney, C.S.M., Jones, R.T., 2010. Does the Agulhas Current amplify global temperatures during super-interglacials? J. Quat. Sci. 25, 839-843. doi:10.1002/jqs.1423.

Turney, C.S.M.M., Jones, R.T., Lister, D., Jones, P., Williams, A.N., Hogg, A., Thomas, Z.A., Compo, G.P., Yin, X., Fogwill, C.J., Palmer, J., Colwell, S., Allan, R., Visbeck, M., 2016. Anomalous mid-twentieth century atmospheric circulation change over the South Atlantic compared to the last 6000 years. Environ. Res. Lett. 11, 064009. doi:10.1088/1748-9326/11/6/064009.

Turney, C., Fogwill, C., Golledge, N., McKay, N., Sebille, E. van, Jones, R., Etheridge, D., Rubino, M., Thornton, D., Davies, S., Ramsey, C.B., Thomas, Z., Bird, M., Munksgaard, N., Kohno, M., Woodward, J., Winter, K., Weyrich, L., Rootes, C., Millman, H., Albert, P., Rivera, A., Ommen, T. van, Curran, M., Moy, A., Rahmstorf, S., Kawamura, K., Dieter-Hillenbrand, C., Weber, M., Manning, C., Young, J., Cooper, A., 2020. Early Last Interglacial ocean warming drove substantial ice mass loss from Antarctica. Proc. Natl. Acad. Sci. doi:10.1073/pnas.1902469117.

Tzedakis, P.C., Drysdale, R.N., Margari, V., Skinner, L.C., Menviel, L., Rhodes, R.H., Taschetto, A.S., Hodell, D.A., Crowhurst, S.J., Hellstrom, J.C., Fallick, A.E., Grimalt, J.O., McManus, J.F., Martrat, B., Mokeddem, Z., Parrenin, F., Regattieri, E., Roe, K., Zanchetta, G., 2018. Enhanced climate instability in the north atlantic and southern Europe during the last interglacial. Nat. Commun. 9, 4235. doi:10.1038/ s41467-018-06683-3.

Vaks, A., Gutareva, O.S., Breitenbach, S.F.M., Avirmed, E., Mason, A.J., Thomas, A.L., Osinzev, A.V., Kononov, A.M., Henderson, G.M., 2013. Speleothems reveal 500,000-year history of Siberian permafrost. Science 340, 183-187.

Vaks, A., Mason, A.J., Breitenbach, S.F.M., Kononov, A.M., Osinzev, A.V., Rosensaft, M., Borshevsky, A., Gutareva, O.S., Henderson, G.M., 2020. Palaeoclimate evidence of vulnerable permafrost during times of low sea ice. Nature 577, 221-225. doi:10.1038/ s41586-019-1880-1.

Wadham, J.L., Arndt, S., Tulaczyk, S., Stibal, M., Tranter, M., Telling, J., Lis, G.P., Lawson, E., Ridgwell, A., Dubnick, A., 2012. Potential methane reservoirs beneath Antarctica. Nature 488, 633-637. doi:10.1038/nature11374.

Wadhams, P., 2012. Arctic ice cover, ice thickness and tipping points. Ambio 41, 23-33. doi:10.1007/s13280-011-0222-9.

Wagner, D., Gattinger, A., Embacher, A., Pfeiffer, E.M., Schloter, M., Lipski, A., 2007. Methanogenic activity and biomass in Holocene permafrost deposits of the Lena Delta, Siberian Arctic and its implication for the global methane budget. Global Change Biol. 13, 1089-1099. doi:10.1111/j.1365-2486.2007.01331.x.

Walter Anthony, K., Daanen, R., Anthony, P., Schneider Von Deimling, T., Ping, C.L., Chanton, J.P., Grosse, G., 2016. Methane emissions proportional to permafrost carbon thawed in Arctic lakes since the 1950s. Nat. Geosci. 9, 679-682. doi:10.1038/ ngeo2795.

Walter, K.M., Zimov, S.A., Chanton, J.P., Verbyla, D., Chapin, F.S., 2006. Methane bubbling from Siberian thaw lakes as a positive feedback to climate warming. Nature 443, 71-75. doi:10.1038/nature05040.

Walter, K.M., Edwards, M.E., Grosse, G., Zimov, S.A., Chapin, F.S., 2007. Thermokarst lakes as a source of atmospheric $\mathrm{CH} 4$ during the last deglaciation. Science 318, 633-636. doi:10.1126/science.1142924.

Wetterich, S., Schirrmeister, L., Andreev, A.A., Pudenz, M., Plessen, B., Meyer, H., Kunitsky, V.V., 2009. Eemian and late glacial/holocene palaeoenvironmental records from permafrost sequences at the Dmitry Laptev Strait (NE Siberia, Russia). Palaeogeogr. Palaeoclimatol. Palaeoecol. 279, 73-95. doi:10.1016/j.palaeo.2009.05.002.

Wetterich, S., Tumskoy, V., Rudaya, N., Kuznetsov, V., Maksimov, F., Opel, T., Meyer, H., Andreev, A.A., Schirrmeister, L., 2016. Ice complex permafrost of MIS5 age in the Dmitry Laptev Strait coastal region (East Siberian arctic). Quat. Sci. Rev. 147, 298-311. doi:10.1016/j.quascirev.2015.11.016.

Wieczorek, S., Ashwin, P., Luke, C.M., Cox, P.M., 2011. Excitability in ramped systems: the compost-bomb instability. Proc. R. Soc. A 467, 1243-1269. doi:10.1098/ rspa.2010.0485.

Wilson, K.J., Turney, C.S.M., Fogwill, C.J., Blair, E., 2016. The impact of the giant iceberg B09B on population size and breeding success of Adélie penguins in Commonwealth Bay, Antarctica. Antarct. Sci. 28, 1-7. doi:10.1017/S0954102015000644.

Wilson, D.J., Bertram, R.A., Needham, E.F., van de Flierdt, T., Welsh, K.J., McKay, R.M., Mazumder, A., Riesselman, C.R., Jimenez-Espejo, F.J., Escutia, C., 2018. Ice loss from the East Antarctic ice sheet during late pleistocene interglacials. Nature 561, 383-386. doi:10.1038/s41586-018-0501-8.

Wouters, B., Helm, V., Flament, T., Wessem, J.M.V., Ligtenberg, S.R.M., Bamber, J.L., 2015. Dynamic thinning of glaciers on the southern Antarctic Peninsula. Science 899-904.

Yau, A.M., Bender, M.L., Robinson, A., Brook, E.J., 2016. Reconstructing the last interglacial at Summit, Greenland: insights from GISP2. Proc. Natl. Acad. Sci. 113, 9710-9715. doi:10.1073/pnas.1524766113. 